\title{
Acerca de la recuperación de Venus y Adonis, de José de Nebra*
}

\author{
About the Process of Recovery of Venus y Adonis, by José de Nebra
}

\section{Luis Antonio González Marín}

DCH-Musicología, IMF-CSIC

Director de Los Músicos de Su Alteza

Real Academia de Nobles y Bellas Artes de San Luis

gzmarin@imf.csic.es

ORCID iD: http://orcid.org/0000-0001-5769-8268

\section{RESUMEN}

El artículo relata el proceso de recuperación de una ópera inédita de José de Nebra, Venus y Adonis (Madrid, 1729), desde la investigación documental en archivos y el estudio crítico de fuentes hasta la preparación de una edición crítica para el estudio y una edición práctica destinada a la interpretación. El proceso concluye con la interpretación, en salas de conciertos, de la obra y su grabación y transmisión por diversos medios. El artículo incluye una reflexión sobre los criterios y límites de la recuperación de patrimonio musical histórico.

\footnotetext{
* Este artículo, y la recuperación musicológica y musical a que se refiere, se inscribe en el Proyecto de $\mathrm{I}+\mathrm{D}+\mathrm{i}$ El patrimonio musical de la España moderna (siglos XVII-XVIII): recuperación, digitalización, análisis, recepción y estructuras retóricas de los discursos musicales (código 309686339-86339-4-17, HAR2017-86039-C2-1-P), Proyecto Coordinado entre equipos del CSIC y de la Universidad de Castilla-La Mancha. Asimismo se beneficia de la actividad del CIDoM (Centro de Investigación y Documentación Musical), Unidad Asociada de la UCLM al CSIC, y del Protocolo General y Convenio Específico de Colaboración firmados entre el CSIC y el Arzobispado de Zaragoza para realizar una investigación exhaustiva en el Archivo de Música de las Catedrales de Zaragoza. La recuperación práctica y producción concertística de la ópera Venus y Adonis por parte de Los Músicos de Su Alteza, bajo la dirección de quien firma este artículo, ha sido posible gracias a la programación Universo Barroco del CNDM (Centro Nacional de Difusión Musical, INAEM, Ministerio de Cultura) en el Auditorio Nacional (Madrid) y a la programación Temporada de Grandes Conciertos de Otoño del Auditorio de Zaragoza, donde el conjunto Los Músicos de Su Alteza es Residente.
} 


\title{
LUIS ANTONIO GONZÁLEZ MARÍN
}

Palabras clave: José de Nebra, ópera barroca española, Venus y Adonis, recuperación de patrimonio musical histórico.

\begin{abstract}
This paper deals with the process of recovery of an unpublished opera by José de Nebra, Venus $y$ Adonis (Madrid, 1729), starting from the documentary research in archives and the critical study of sources and continuing with the preparation of a critical and practical edition for both study and performance. The process concludes with the performance, in concert halls, of the work and its recording and transmission by various media. The article includes a reflection on the criteria and limits of the recovery of historical musical heritage.
\end{abstract}

Key words: José de Nebra, Spanish baroque opera, Venus y Adonis, recovery of historical musical heritage.

González Marín, L. A. (2018). Acerca de la recuperación de Venus y Adonis, de José de Nebra. Cuadernos de Investigación Musical, 6 (extraordinario), 115-155.

doi: 10.18239/invesmusic.v0i0.1943

Llevar a cabo la recuperación "integral" de una obra musical totalmente desconocida, de extensión y complejidad notables, y tratar de completar del proceso en todo su desarrollo, desde la pesquisa archivística hasta la interpretación en concierto (con sus consiguientes grabación, filmación y emisión por parte de la radio y televisión públicas), puede convertirse en un verdadero calvario e incluso conducir a estrepitosos fracasos. Sin embargo, si se cuenta con medios adecuados (lo que no necesariamente implica una astronómica inversión pecuniaria -aunque cierta holgura sea no sólo conveniente, sino necesaria-, sino, sobre todo, otro tipo de facultades) y la fortuna acompaña, puede constituir una experiencia inolvidable, muy trabajosa sin duda, pero sumamente satisfactoria y coronada por el éxito. Esto es lo que ha sucedido con Venus y Adonis, ópera de José de Nebra estrenada en 1729 y recuperada para el público en 2018, y esta es la experiencia que voy a relatar en las siguientes páginas.

No es preciso extenderse de nuevo en una presentación de la figura de José de Nebra (*Calatayud, Zaragoza, 1702; †Madrid, 1768), compositor que en las últimas décadas viene suscitando la atención de musicólogos e intérpretes, y poco a poco también de programadores y públicos ${ }^{1}$. La incuestionable calidad de su producción musical de todo género (música religiosa litúrgica y paralitúrgica, música teatral, de cámara e instrumental de tecla) es ya bien conocida, aunque muchas de sus composiciones sigan todavía esperando la publicación de buenas ediciones y su reestreno en condiciones óptimas. En cualquier caso, las recientes investigaciones, ediciones y recuperaciones aportan nuevos materiales y

\footnotetext{
1 Bibliografía actualizada sobre Nebra podrá encontrarse en mis últimos trabajos publicados al respecto, como el artículo "A vueltas con José de Nebra. Pensamientos sobre autorías y atribuciones" (González Marín, 2016: 91-108).
} 


\section{ACERCA de La RECUPERACIÓN DE VENUS Y ADONIS, DE JOSÉ DE NEBRA}

resultados que enriquecen nuestra visión y comprensión del legado del compositor aragonés.

José de Nebra gozó en vida de una altísima consideración en diversos terrenos de la práctica musical, como organista -cargo que ejerció en las Descalzas y después en la Real Capilla-, clavecinista y maestro de ilustres discípulos como la propia reina María Bárbara de Portugal, compositor de música religiosa litúrgica y paralitúrgica... Pero hay un campo de su actividad, que desde muy joven desarrolló siempre en Madrid, que llama poderosamente la atención en un músico en principio vinculado a ambientes eclesiásticos: su exitoso trabajo para los teatros públicos y su permanente relación con el mundo de la escena. De hecho, Nebra residía en la madrileña Plazuela del Ángel, centro estratégico de la farándula, a dos pasos de los corrales -que Nebra vio remodelar como coliseos a la italiana- de la Cruz enfrente de su casa- y el Príncipe, junto a la parroquia de San Sebastián, donde sería enterrado y donde radicaba la cofradía de la Novena, que agrupaba sobre todo a gentes del teatro, de la música y de otras profesiones artísticas.

Desde al menos 1723 Nebra componía regularmente música para funciones teatrales a las que podía asistir cualquier ciudadano mediante el pago de una entrada. Posiblemente accedió a estos círculos teatrales a través del contacto con dos músicos y un dramaturgo con los que trabó relación. Uno fue el catalán José de San Juan (*Cataluña, 1685c; * Madrid, 1747c.) [López-Calo, 1999ss], maestro de capilla bajo cuyas órdenes Nebra trabajó en las Descalzas, y notable zarzuelista. El segundo era el mallorquín Antonio Literes (*Artá, 1673; †Madrid, 1747), con quien coincidió en la Real Capilla -donde éste trabajaba como violóny en la cámara de los Duques de Osuna; Literes fue el más célebre compositor de zarzuelas del primer tercio del siglo XVIII, sobre todo a partir de su triunfo con Acis y Galatea $(1708)^{2}$. El tercero, y seguramente el más influyente, fue José de Cañizares (*Madrid, 1676; †Madrid, 1750) ${ }^{3}$, prolífico dramaturgo y fiscal de comedias de los teatros madrileños, que trabajaba en la contaduría de los Duques de Osuna. Cañizares y Nebra colaboraron en varias decenas de obras teatrales con música, y es muy posible que el primero introdujera al joven músico en el mundo de la escena.

En sus primeros años como compositor para el teatro (1723-1728), Nebra puso música diversos a autos sacramentales ${ }^{4}$, comedias de diferentes géneros y piezas de teatro breve, obras en las que, según tradición hispánica, alternaban pasajes en música con otros hablados, como en las zarzuelas. Los esponsales del infante Fernando de Borbón -futuro Fernando VI- con María Bárbara de Portugal, previstos para 1726 pero verificados en enero de 1728, permitieron a Nebra componer para la corte un acto de una ópera a la

\footnotetext{
${ }^{2}$ Cfr. González Marín, 2002; Pizà Prohens, 2002.

${ }^{3}$ Cfr. Martín Moreno, 1979; Leal Bonmatí, 2007: 487-518.

${ }^{4}$ Acerca de las composiciones de Nebra para autos sacramentales, véase mi introducción ("Apunte biográfico de José de Nebra", "El legado zaragozano de José de Nebra", "José de Nebra y los autos sacramentales", "La fuente musical y la producción de La divina Filotea" y "La música de La divina Filotea") (González Marín, 2008a: 11-29). Recientes hallazgos de nuevas fuentes musicales de autos sacramentales puestos en música por Nebra darán lugar a una próxima publicación, con una edición completa y estudio introductorio de la música de los cuatro autos supervivientes.
} 


\section{LUIS ANTONIO GONZÁLEZ MARÍN}

italiana enteramente cantada - Amor aumenta el valor, con libreto de Cañizares ${ }^{5}$ - y de paso medirse con dos compositores italianos -Facco y Falconi-, autores de los otros actos de la misma. La obra es de una calidad fuera de lo común, pero por alguna razón jamás se volvió a encomendar al aragonés otra composición para el teatro de corte, que se sepa. Sin embargo, cabe pensar que esta experiencia con la ópera de tradición italiana -aunque con texto en castellano- fue provechosa para el autor, como demuestran sus trabajos posteriores para los teatros públicos.

Así, el año siguiente del estreno de Amor aumenta el valor el tándem Cañizares-Nebra pone en escena, en un teatro público (o, mejor dicho, en dos sucesivamente, según parece), "una" Melodragma o Melodramma, esto es, una ópera, cantada de principio a fin. Hasta el presente la pieza ha arrastrado algunas confusiones que tal vez ahora comiencen a despejarse gracias a la investigación sobre las fuentes musicales, literarias y documentales desarrollada para poner en pie su recuperación. Sabemos, en todo caso, que el 12 de noviembre de 1729 la compañía de Manuel de San Miguel estrenaba en el teatro del Príncipe La Melodramma, o las tres comedias en una, con libreto de Cañizares y música de Nebra. Al parecer, un mes después, el 12 de diciembre, se estrenaba en el teatro de la Cruz una obra titulada Venus y Adonis. A continuación veremos qué tienen en común.

Debemos a Antonio Martín Moreno el hallazgo y la primera noticia publicada sobre Venus y Adonis. Tal como el musicólogo granadino relata en el tomo correspondiente al siglo XVIII de la Historia de la música española de Alianza Editorial (1985), él mismo tuvo la fortuna de descubrir la fuente musical -única conocida hasta la fecha- de Venus y Adonis entre los fondos del archivo del Padre Nemesio Otaño, en el Santuario de Loiola (Guipúzcoa). Martín Moreno realizó una breve descripción de la fuente, indicando nombre del copista (Antonio Palomino el menor) y fecha (1733), así como número y contenido de los cuadernos que se conservan, advirtiendo con razón que se trata de una fuente incompleta ("un manuscrito encuadernado con las partes de voces y acompañamiento, con 113 páginas, y otro con la parte del violín primero, con 18 páginas, faltando lamentablemente los restantes instrumentos.") [Martín Moreno, 1985: 388-389] e indicando, de nuevo con tino, que la fuente no deja claro "si se trata de la fecha del estreno o de la copia". Seguramente la conservación incompleta de la fuente, así como la propia indicación al respecto por parte de Martín Moreno, sirvieron de elemento disuasorio para no pocos musicólogos e intérpretes a la hora de afrontar un posible trabajo en profundidad sobre Venus y Adonis.

Posteriormente, María Salud Álvarez, en el amplio estudio sobre Nebra que constituyó su Tesis Doctoral, alude a Venus y Adonis, de 1733, conjeturando que tal vez pudiera tratarse de una pieza para un coliseo privado por ignorarse lugar y fecha del estreno. Asimismo describe someramente la fuente, ofreciendo un listado incompleto (con

\footnotetext{
5 Véase mi estudio y edición: Giacomo Facco / José de Nebra: Amor aumenta el valor (González Marín, 2011). Asimismo, véase la grabación que dirigí con Los Músicos de Su Alteza (2010). José de Nebra: Amor aumenta el valor. París: Alpha (Colección Ut pictura musica) [Entidades patrocinadoras: Université Laval (Québec, Canadá), Fondation Orange, Gobierno de Aragón], ALPHA 171.
} 


\section{ACERCa de LA RECUPERACIÓN DE VENUS Y ADONIS, DE JosÉ DE NEBRA}

incipit vocales) de arias y dúos ${ }^{6}$. En otro lugar Álvarez se refiere a la colaboración de Nebra con Cañizares en 1729 como compositor de la música de La melodrama, o las tres comedias en una, trabajo por el que Nebra habría percibido 960 reales (Álvarez Martínez, 1993: 28; 187 188), según documentación del Archivo Histórico de la Villa de Madrid ${ }^{7}$. La razón por la que cito aquí este -o esta, según la adscripción de género al término en el siglo XVIIImelodrama, aparentemente sin relación con la ópera que nos ocupa, se comprenderá más abajo.

En su catálogo de la música teatral española del siglo XVIII, Rainer Kleinertz, basándose en los estudios de René Andioc y Mireille Coulon, cita Venus y Adonis ${ }^{8}$, indicando fecha y lugar de estreno (Madrid, teatro de la Cruz, 12 de diciembre de 1729), atribuyendo el libreto -por entonces desconocido, como Kleinertz afirma- al dramaturgo Alonso de Anaya y Espinosa, y la música a Nebra, y proponiendo que tal vez éste compusiera la música para el estreno de 1729 y la fecha (1733) de la fuente musical conocida, conservada en el archivo del padre Otaño de Loiola, aluda al momento de la copia de Antonio Palomino. Sugiere asimismo que tal vez fuera Nebra el autor de la música de un Venus y Adonis en dos jornadas que ejecutaron los músicos de la catedral de Palma de Mallorca en 1739, obra ya citada por Cotarelo (1917: 279-180) que, a lo que vamos sabiendo, nada tiene que ver -salvo la coincidencia de título y argumento, pero no de libreto ni presumiblemente de música- con la ópera de Nebra que nos ocupa, y que, probablemente, fue compuesta por Carlos Julián, oboísta militar y primer violín de la capilla catedralicia balear. En otro lugar, y siempre con base en la Cartelera teatral madrileña de Andioc/Coulon, Keinertz se refiere a Las tres comedias en una, indicando autor de texto (José de Cañizares) y música (José de Nebra), fecha y lugar de estreno (12 de noviembre de 1729 en el teatro del Príncipe de Madrid, por la compañía de Manuel de San Miguel) ${ }^{9}$. Ambas piezas, Venus y Adonis y Las tres comedias en una, ambas descritas como melodramas, y producidas y estrenadas, según puede deducirse de las fuentes documentales, con un mes de diferencia, no parecían estar, para los musicólogos, relacionadas entre sí.

Pero ya en fecha tan temprana como 1899, el Catálogo de las piezas de teatro que se conservan en el Departamento de Manuscritos de la Biblioteca Nacional, coordinado por Antonio Paz y Meliá, ponía en estrecha relación ambos títulos. La entrada 47 del catálogo dice así:

\section{7-Adonis y Venus. \\ Melodrama.}

\section{E. Música.-Ni Marte con iras}

\footnotetext{
${ }^{6}$ Álvarez realiza la primera descripción conocida de los números de que consta la fuente, pero tal vez sólo pudo realizar una revisión superficial de la misma, pues indica que la música de Venus y Adonis consta de "once arias, con sus correspondientes recitativos, dos dúos y un cuatro final", cuando en realidad la fuente musical contiene, aparte de veinticuatro recitados, tres cuatros (en realidad dos, más una repetición del primero), doce arias y tres dúos (Álvarez Martínez, 1993: 30, 137-139).

${ }^{7}$ Los documentos en cuestión, que Ávarez transcribe, junto con otros muchos más, fueron ya publicados en 1910 por Cristóbal Pérez Pastor (Pérez Pastor, 1910: 87).

8 Kleinertz, 2003, II: 238; Andioc y Coulon, 1996: 874.

${ }^{9}$ Kleinertz, 2003, II: 184; Andioc y Coulon, $1996: 866$.
} 


\section{LUIS ANTONIO GONZÁLEZ MARÍN}

A. ó auditorio, nuestro error.

I I hoj., 4..$^{\circ}$, 1. del s. XVIII.

En la portada dice: «Es de Manuel

Guerrero. —Se hizo en Valencia.»

A la cabeza del reparto: «Segunda jor-

nada de «Las tres comedias en una»

(que es comedia de Cañizares)

([Paz y Meliá], 1899: 13).

Esta sugestiva entrada catalográfica me permitió no sólo localizar un libreto manuscrito, que conserva la Biblioteca Nacional, sino comprender la relación entre dos obras calificadas como "melodramas" que se ofrecieron al público madrileño en el breve espacio de un mes, a finales de 1729, e identificar Venus y Adonis como una parte, en concreto el segundo acto, de Las tres comedias en una.

A falta de una investigación más exhaustiva, a día de hoy no se conoce el texto completo de Las tres comedias en una, ni su contenido completo, pero sí tenemos, conservado en un ejemplar manuscrito, el libreto de su segunda jornada, que era una pieza totalmente cantada, lo que hoy llamaríamos "ópera" y en aquel momento dieron en llamar "melodrama" y aun "melodragma". De su lectura se comprueba que se trata de una obra teatral cerrada, con principio y fin y sentido completo en sí misma, y que posiblemente el espectáculo Las tres comedias en una, con texto de José de Cañizares, se ajustaba al modelo de "comedia triple" establecido probablemente por Calderón en Los tres mayores prodigios (1636) y revisitado en diversas ocasiones a lo largo del siglo XVII, en que tres argumentos diferentes e independientes, vinculados por algún elemento temático común, conformaban las tres jornadas de una función ${ }^{10}$. Cañizares, buen conocedor del teatro calderoniano que por aquellas fechas (1729) acreditaba ya una dilatada y sólida trayectoria como dramaturgo y fiscal de comedias de la Corte, es bien conocido como autor documentado de Las tres comedias en una (Andioc y Coulon, 1996: 866), obra que debió de circular impresa o manuscrita durante algún tiempo, pues figuraba como tal en compilaciones setecentistas, como el Índice general alfabético de todos los titulos de comedias, que se han escrito por varios autores, antiguos, y modernos. $Y$ de los autos sacramentales, y alegóricos, assi de Don Pedro Calderón de la Barca, como de otros autores clásicos, de $1735^{11}$, y ochocentistas, como el Catálogo de piezas dramáticas publicadas en España, desde el principio del siglo XVIII hasta la época presente que se incluyó como adenda al Prólogo de las Obras dramáticas y líricas de D. Leandro Fernández de Moratín en su

\footnotetext{
${ }^{10}$ Una explicación de este tipo de espectáculos se encuentra en Sáez, 2014: 479-493.

11 INDICE GENERAL / ALFABETICO / DE TODOS LOS TITULOS / DE COMEDIAS, / QUE SE HAN ESCRITO / POR VARIOS AUTORES, / ANTIGUOS, Y MODERNOS. / Y / DE LOS AUTOS SACRAMENTALES, / Y ALEGÓRICOS, / ASSI DE DON PEDRO CALDERON / DE LA BARCA, / COMO DE OTROS AUTORES / CLASICOS. / ESTE INDICE Y TODAS LAS COMEDIAS, / y Autos que se comprehenden en èl, se halla- / ràn en casa de los Herederos de Francisco / Medèl del Castillo, frente de las Gradas de San / Felipe el Real. / En MADRID: En la Imprenta de Alfonso de Mora. / Año M. DCC. XXXV. En la página 114 se lee: "Tres Comedias en Una, — de D. Joseph Cañizares.".
} 


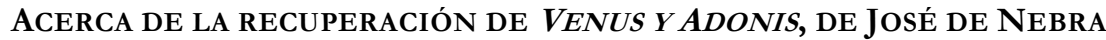

edición parisina de $1825^{12}$ y posteriormente se reimprimió en España en diversas ocasiones; aparece citada igualmente en el catálogo de Cayetano Alberto de la Barrera (Barrera y Leirado, 1860: 70).

La documentación conservada en el Archivo Histórico de la Villa de Madrid adscribe inequívocamente la autoría literaria de Las tres comedias en una a José de Cañizares, y la musical a José de Nebra, y establece como fecha de estreno el 12 de noviembre de 1729. Las cartas de pago a los autores se firmaron el 15 del mismo mes. En una de ellas Cañizares daba fe de haber recibido 1.500 reales de vellón "por la comedia nueba que escribi, intitulada Las tres comedias en una, ó melodrama que se esta executando en dichos corrales este presente mes", y aparecen dos cartas firmadas por Nebra, una por 960 reales "que se me dio por la musica que hize nueva para la comedia intitulada Las tres comedias en una, que se esta executando en los dias de este presente mes.", y otra por 900 reales por la "musica que hice para la comedia intitulada Las tres comedias en una, la qual se esta executando en los

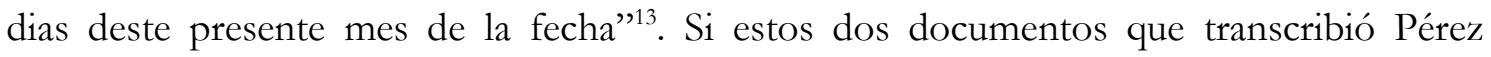
Pastor corresponden en efecto a dos pagos diferentes, Nebra habría percibido, de manera anómala, unos emolumentos superiores a los del dramaturgo, tal vez justificables por tratarse acaso de un espectáculo, en tres jornadas, todo él en música, y posiblemente también por ensayar la música con las cantantes.

Parece que Las tres comedias en una sólo permaneció en cartel durante cinco días en el teatro del Príncipe, en manos de la compañía de Manuel de San Miguel, pero curiosamente una función titulada Venus y Adonis reaparece un mes más tarde, el 12 de diciembre, en el teatro de la Cruz. Aunque no hay pruebas que lo confirmen, tengo la impresión de que, dada la extensión de Venus y Adonis, segunda jornada de Las tres comedias en una, y contando con las características de su libreto (una obra cerrada, de argumento completo) y el nivel de su música, tal vez se extrajera del larguísimo y puede que no del todo exitoso espectáculo original para conformar una función independiente, en una inmediata reposición en el teatro vecino, el de la Cruz. Es una hipótesis que podría explicar la existencia de al menos una copia de la música de Venus y Adonis considerada como melodrama independiente.

Lo cierto es que en la actualidad conservamos, separadamente, dos fuentes, una musical y una literaria, que corresponden a la misma obra, Venus y Adonis, y que aportan informaciones diferentes.

La única fuente literaria conocida hasta el presente es un manuscrito conservado en la Biblioteca Nacional de Madrid bajo la signatura $\boldsymbol{E}-\mathbf{M n}$, Mss/17449/17, que contiene el libreto o texto completo del melodrama. Su título, un tanto equívoco, dice: $\uparrow$ / Melodrama / de / Adonis / y / Venus / Es de Manuel Guerrero. En otra línea, y de otra mano, se lee: "Se hizo en Valencia". El manuscrito consiste en un cuaderno cosido en cruceta con bramante,

12 OBRAS / DRAMATICAS Y LIRICAS / DE D, LEANDRO FERNANDEZ / DE MORATIN, / Entre los Arcades de Roma, Marco Celenio. / UNICA EDICION RECONOCIDA POR EL AUTOR. / TOMO PRIMERO. / PARIS, / IMPRENTA DE AUGUSTO BOBÉE, / CALLE DE LA TABLETTERIE, Nº9. / 1825, página xlviij (48).

${ }^{13}$ Los documentos fueron recogidos por Cristóbal Pérez Pastor (1910: 87) así como, en parte, por María Salud Álvarez Martínez (1993: 187-188), quien sólo consigna el pago de 960 reales a Nebra. 


\section{LUIS ANTONIO GONZÁLEZ MARÍN}

formado por catorce folios sueltos, en formato vertical, con medidas de 204 x 156 mm. Los dos primeros folios fueron numerados a lápiz y en romanos en la Biblioteca (I y II). A partir del tercero, donde empieza el texto, existe una foliación a tinta, presumiblemente original, contemporánea a la copia del texto (de 1 a 11). El último folio, que hace las veces de cubierta posterior, no está numerado.

Es justamente el título que aparece en el comienzo del texto, precediendo a la primera acotación, el que conecta este libreto con los documentos vistos y con la fuente musical que se describirá después. Encabezando el folio 1r se lee:

† / Segunda Jorna[da] de las tres come- / dias en una Melodramma / De Adonis Y Venus $/=====$ /

Personas $/===/$ Adonis $=$ Venus $=$ Marte $=/$ Cibeles $=$ Clarin $=$ Celfa $=/$ Ninfas $=$ Comparsa $=$ Musica $=/======/$ Dentro Cajas y Clarines á lo Lejos, y despues de el / quatro salen pasando las Ninfas y Venus. / - . - - - .

Si el título inicial del manuscrito ( $\dagger$ / Melodrama / de / Adonis / y / Venus / Es de Manuel Guerrero) podía inducir a pensar que Guerrero fuese el autor del texto, el subtítulo que vincula la pieza a Las tres comedias en una adscribe implícitamente su autoría a José de Cañizares. Parece razonable interpretar que la locución "Es de Manuel Guerrero" se refiere únicamente a la propiedad del manuscrito, que posiblemente le perteneció. Casi con seguridad hemos de identificar a este Manuel Guerrero con el que desde mediados del siglo XIX ha sido citado erróneamente con el nombre de Manuel Vicente Guerrero, actor, cantante, dramaturgo, poeta, polemista y empresario activo en la primera mitad del siglo $\mathrm{XVIII}^{14}$. Manuel Guerrero, que disfrutó de una notable formación intelectual (pues había estudiado Humanidades, Filosofía, Teología y Cánones en el Colegio Imperial de la Compañía de Jesús), formó parte durante varios años de la compañía de Manuel de San Miguel, que había estrenado Las tres comedias en una, y es posible que colaborara de algún modo con José de Nebra cuando revisó el viejo libreto de Antonio de Zamora para Viento es la dicha de Amor, a la que Nebra había puesto música en 1743, con vistas a la reposición de $1752^{15}$.

Por los indicios documentales antes vistos y por las propias características literarias del libreto, creo que puede atribuirse su composición a José de Cañizares sin demasiadas dudas, aunque hasta el presente ningún investigador lo haya aventurado.

\footnotetext{
${ }^{14} \mathrm{Al}$ parecer Manuel y Vicente Guerrero eran hermanos, y desde, que se sepa, el citado Catálogo de Cayetano Alberto de La Barrera, se les cita confusamente como si fueran una sola persona, "Manuel Vicente". Para clarificar la identidad de Manuel Guerrero, véase Di Pinto (2015: 97-140). Sorprendentemente, la voz de Jerónimo Herrera Navarro, "Guerrero, Manuel Vicente", en Diccionario Biográfico Español de la Real Academia de la Historia (edición electrónica, http://dbe.rah.es/biografias/73505/manuel-vicente-guerrero), sigue combiando ambos nombres; nótese además que en esta voz se atribuye Adonis y Venus a Guerrero, y erróneamente se sitúa el manuscrito, signatura “17449 (17)" en la Biblioteca Municipal de Madrid.

15 Sobre esta zarzuela y su compleja historia, véase Leza Cruz, 2011.
} 


\section{ACERCa de LA RECUPERACIÓN DE VENUS Y ADONIS, DE JosÉ DE NEBRA}

El libreto que poseyó Manuel Guerrero divide la jornada operística en dieciocho escenas, a la italiana, en función de las salidas o entradas de personajes. Aparte de que algunas escenas comprendan varios números (recitados, arias), la división de aquellas no siempre coincide exactamente con los pasos de un número a otro, pues se producen varios cambios de escena durante pasajes de recitado, lo que genera un buen ritmo dramático en lo que respecta a la liaison des scènes.

Los personajes que intervienen, aparte de la "Música" (coro, que probablemente cantaban los mismos protagonistas, como era costumbre) y comparsas, son seis: Venus, Adonis, Marte, Cibeles y los graciosos Celfa y Clarín. El argumento de Venus y Adonis era ya entonces un tópico en la dramaturgia musical ${ }^{16}$, y la versión de Cañizares parece buscar sus raíces en un melodrama calderoniano que, olvidada la experiencia primigenia probablemente fallida hasta cierto punto- de La selva sin Amor, se constituyó en piedra fundacional del melodrama en España: La púrpura de la rosa (Madrid, 1660, con motivo de la boda de María Teresa de Austria, hija de Felipe IV, con Luis XIV de Francia), a la que Juan Hidalgo puso una música que, muy posiblemente, es a grandes rasgos la misma que Tomás de Torrejón y Velasco adaptó para el estreno limeño de 1701 (Stein, 1999). La púrpura de la rosa fue también un melodrama en un solo acto, y no deja de parecer sintomático que, aparte de tomar prestados la trama y los personajes principales, Cañizares de a su graciosa el mismo nombre -Celfa- que lleva la de la pieza calderoniana; igualmente llama la atención que el gracioso de Venus y Adonis responda al mismo nombre -Clarín- que el criado del protagonista de la otra ópera calderoniana compuesta para la citada fiesta de 1660, Celos aun del aire matan, con la que Venus y Adonis comparte, en cierto modo, la temática, pues los celos son el desencadenante de la tragedia en ambos casos.

La acción de Venus y Adonis transcurre en Chipre, en cuyas aguas nació Venus, que reina en la isla. Las habladurías sobre un joven llamado Adonis que supera en belleza a Venus enojan a la diosa, que decreta la muerte del muchacho. Marte, enamorado de Venus, trata de ganarse el favor de ésta tendiendo una trampa mortal a Adonis, quien secretamente ama a su vez a la diosa. Venus descubre al bello Adonis dormido y de inmediato se enamora perdidamente de él. Enterada de su identidad, teme ahora que Marte le de muerte. Marte ha prevenido con Cibeles que un gigantesco jabalí acabe con el joven, que, apasionado de la caza como es, contraviniendo los ruegos de Venus se apresta a combatir a la fiera. Adonis cae malherido por el jabalí y, aunque Venus trata de socorrerlo, se desangra, muriendo feliz en brazos de su amada, a quien pide que no desdeñe el cariño de Marte. La sangre de Adonis y la que ha brotado de un pie de Venus, herida por una espina de rosal al correr en pos de Adonis, se unen tiñendo las rosas, antes blancas, de rojo púrpura, y el propio Adonis es transformado por Venus en la planta que se conoce como anémona, que tiene hojas parecidas al perejil y da grandes flores que semejan amapolas de diferentes colores: rojo, púrpura, azul y blanco. Todos, dioses y mortales -éstos, los graciosos Celfa y Clarín, que previamente han protagonizado varias escenas cómicas con textos equívocos-, celebran el milagroso fin de los amores de Venus y Adonis.

16 Véase Pastor Comín, 2008: 131-150. 


\section{LUIS ANTONIO GONZÁLEZ MARÍN}

La única fuente musical conocida hasta el momento, excepto una concordancia de un aria de la que después se hablará, es el citado manuscrito que descubrió Martín Moreno, conservado en el Archivo y Biblioteca Musical del Padre Otaño, en el santuario jesuítico de Loiola, bajo la signatura B.M. 60 o B-6. Se trata de dos cuadernos apaisados, que contienen, respectivamente, las partes vocales más el continuo (en partitura), y la parte de violín 1. Las fuentes musicales de obras dramáticas de Nebra que han sobrevivido pertenecen a diferentes tipologías ${ }^{17}$ : disponemos de partituras completas, algunas de ellas autógrafas (las zarzuelas Vendado Amor es, no ciego y Donde hay violencia no hay culpa) y otras debidas a copistas (la ópera Amor aumenta el valor, la zarzuela Para obsequio a la deidad nunca es culto la crueldad, y Iphigenia en Tracia, o el auto sacramental Amar y ser amado y divina Philotea), todas ellas destinadas a su conservación, y también de juegos de partichelas más o menos completos o fragmentarios (la zarzuela Viento es la dicha de Amor, los autos El diablo mudo, Andrómeda y Perseo y La redención de cautivos, la comedia El dómine Lucas o los bailes Las granaderas y alondón y Viva el cacique) confeccionados para su uso, como materiales de orquesta con vistas a las ejecuciones de tales piezas. Lo dos cuadernos conservados de Venus y Adonis parecen pertenecer a esta última categoría, esto es, posiblemente proceden de una copia completa de la partitura, extraída en diferentes partes anotadas separadamente en sus correspondientes cuadernillos, de las cuales varias se habrían perdido. Veamos a continuación una descripción de la fuente.

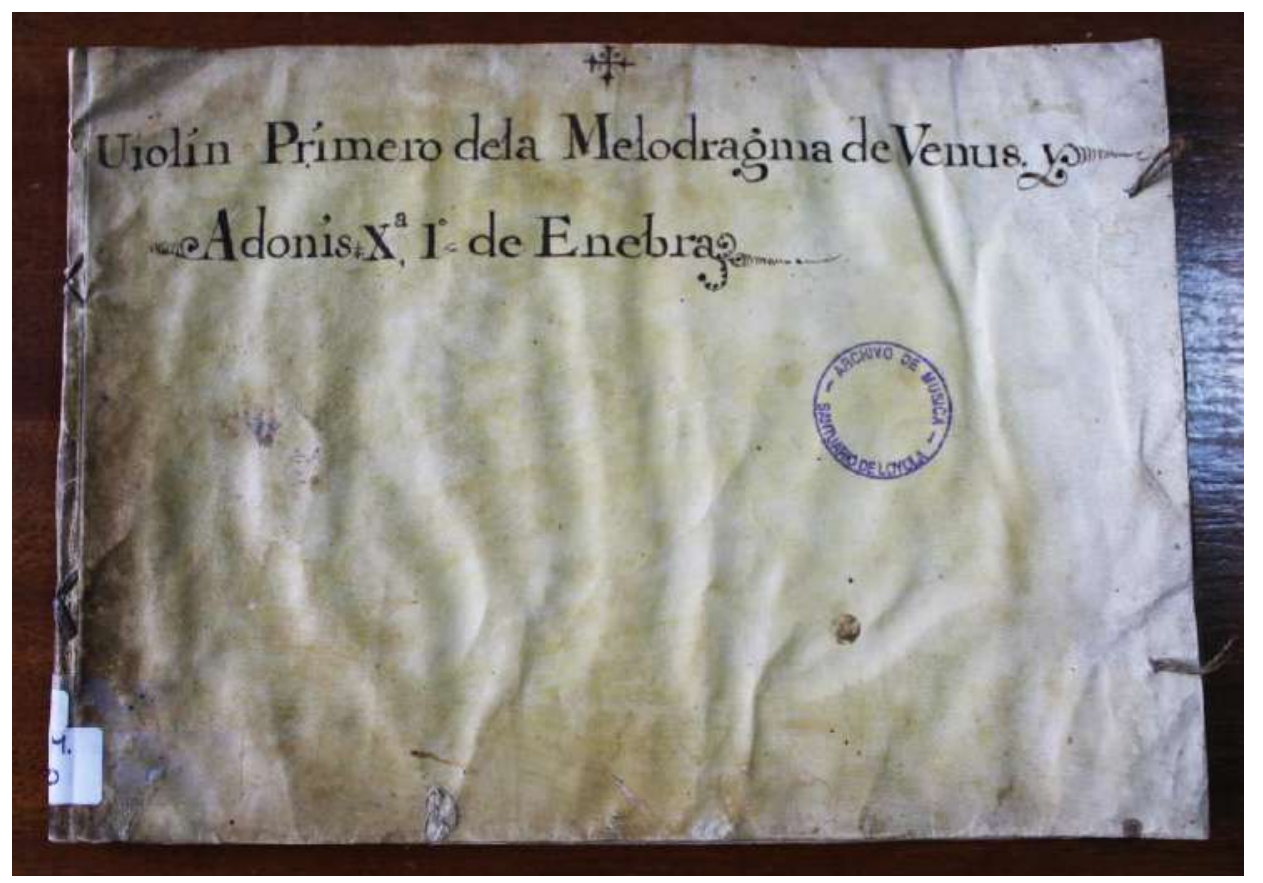

Fig. 1: Cuaderno del Violín 1, con título en cubierta: + / Uiolin Primero de la Melodragma de Venus y / Adonis. $X^{a}$. I de Enebra.

\footnotetext{
17 Sobre los diferentes formatos de conservación, generados por diversas prácticas, de las fuentes musicales dramáticas españolas expuse una reflexión en mi artículo "El teatro musical español del siglo XVII y sus posibilidades de restauración” (González Marín, 1993: 63-102).
} 


\section{ACERCa de la ReCUPERACión de VenUS y ADONIS, de José de Nebra}

1) Cuaderno del Violín 1, con título en cubierta: $\uparrow$ / Uiolin Primero de la Melodragma de Venus y / Adonis. $X^{a}$. I ${ }^{o}$ de Enebra. Formado por tres cuadernillos (numerados) cosidos, con cubiertas de pergamino (y cordones para cerrar el volumen) y guardas. Medidas: 210 x 294 mm. (encuadernación, con lomo de unos $5 \mathrm{~mm}$ ) y 208 x $294 \mathrm{~mm}$. (papel). Hay dos tipos de papel: uno grueso, de alto gramaje, para la música, paginado modernamente a lápiz (pp. 120, numeradas incluso las dos últimas páginas, con pautas pero sin música), con marca de agua con letras S_P ${ }^{18}$ en pp. 11-12, 19-20 y posiblemente otras; y otro más fino para guardas y hojas de respeto (una al comienzo y otra al final); en la hoja de respeto final del mismo (de otro papel de menor gramaje) se aprecia marca de tipo genovés con letras SP. Los pliegos de música constan de 10 pentagramas por página, con sus márgenes establecidos mediante dobleces en el papel. Parece que se trata de un copista diferente del de la partitura vocal.

Llama la atención que en el título de la cubierta (y también en el de la primera página de música: "Violin $1^{\circ}$. Melodragma Venus y Adonis $=\mathrm{X}^{\mathrm{a}} \cdot 1^{\mathrm{o}} .=$ de Enebra=") aparezca la indicación " $\mathrm{X}^{\mathrm{a}}$. $\mathrm{I}^{\mathrm{o}}$ ”, es decir, "Jornada primera". Posiblemente el copista, tal vez habituado a trasladar obras en dos y tres jornadas, desconocía que se trataba de un melodrama en una sola jornada, aunque quizá pueda ser indicio de que, en alguna posible reposición, se previera que Venus y Adonis constituyera la primera jornada de un espectáculo más largo, del mismo modo que fue segunda de Las tres comedias en una en su estreno.

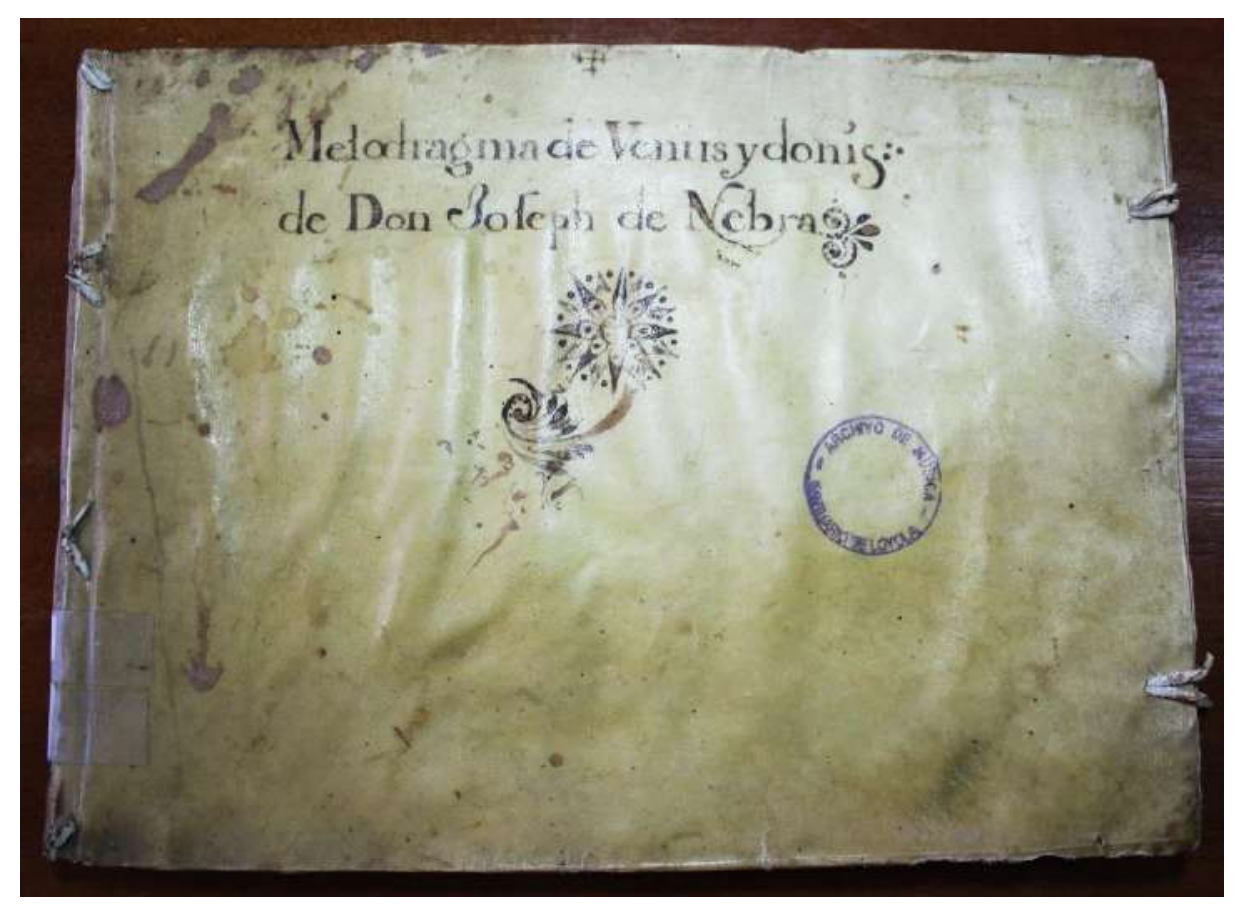

Fig. 2: Cuaderno de voces y continuo, con título en cubierta: $\uparrow$ / Melodragma de Venus y donis / de Don Joseph de Nebra.

\footnotetext{
18 Estas filigranas aparecen frecuentemete en los papeles usados por Nebra y su entorno. Véase mi artículo "Una reflexión sobre la música de tecla de José de Nebra" (González Marín, 2008b: 591-612). Véase también Yáñez Navarro, 2018: 167-186.
} 


\section{LUIS ANTONIO GONZÁLEZ MARÍN}

2) Cuaderno de voces y continuo, con título en cubierta: $\uparrow$ / Melodragma de Venus y donis / de Don Joseph de Nebra. Formado por 13 cuadernillos numerados, cosidos, con cubiertas de pergamino (encuadernación en pergamino, cosida, con badanas para cerrar el volumen, que se han roto: en la cubierta posterior se conserva el botón de hueso o pasta blanca del cierre inferior) y guardas, sin hojas de respeto. Medidas: 220 x $296 \mathrm{~mm}$. (encuadernación, con lomo de $20 \mathrm{~mm}$, curvado) y 218 x $298 \mathrm{~mm}$. (papel). Papel grueso, de alto gramaje, paginado modernamente a lápiz (1-113; no se numera la última página, que contiene pautas pero carece de música), con marca de agua S_P en varios lugares. Hojas pautadas con 10 pentagramas por página, con sus márgenes establecidos mediante dobleces en el papel. Parece que se trata de un copista diferente del de la parte del violín 1.

En este cuaderno de voces y bajo, tipo de partitura vocal que en la época se solía conocer como "parte de apuntar" o "parte del clave", por estar destinada probablemente al instrumento principal de continuo en ensayos y ejecución, no se encuentra la indicación equívoca sobre la división de la obra en jornadas que sí aparece en la parte de violín 1. El título que se lee en la primera página de música es: “† / Melodragma de Venus y Ádonis de D. Joseph de Nebra=". En la última página con música se lee: "FIN de la JORNADA / de $\mathrm{D}^{\mathrm{n}}$ Joseph Enebra= trasladada por Antonio Palomino el menor Año de 1733", lo que parece indicar que todo el melodrama es una jornada o acto de un espectáculo más largo, pero no que Venus y Adonis constituya en sí una pieza en varias jornadas, lo que parece coincidir con el libreto descrito previamente.
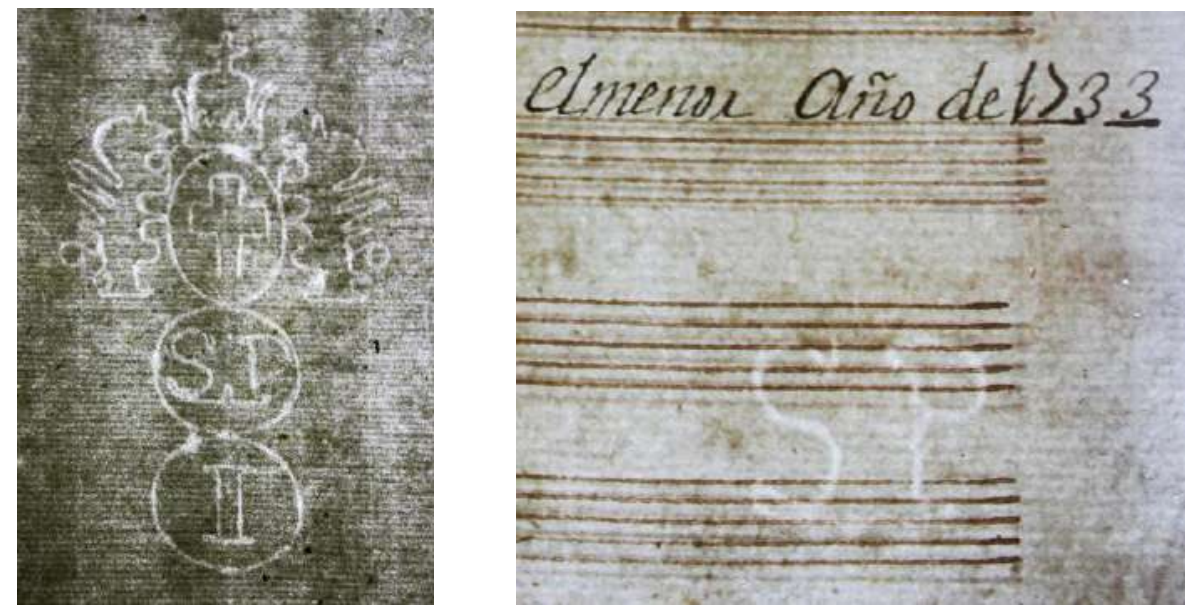

Fig. 3: Marcas de agua del manuscrito musical de Venus y Adonis. A la izquierda, filigrana de tipo genovés en guarda del cuaderno de violín 1. A la derecha, letras S_P en última página del cuaderno de voces y bajo. Archivo y Biblioteca Musical Padre Otaño, Loiola.

Veamos a continuación los números musicales en que se divide la obra, tomando como referencia la partitura vocal ${ }^{19}$ :

19 Se anotan las partes vocales ( $\mathrm{S}=$ soprano, $\mathrm{T}=$ tenor) e instrumentales (v1= violín $1^{\circ}$, acompto.=acompañamiento o bajo continuo) conservadas o sugeridas por la fuente, más armadura, tono (en el caso de los recitativos, que carece de armadura, notas inicial y final del bajo) y compás. Los incipit 
ACERCA de LA RECUPERACIÓN DE VENUS Y ADONIS, DE JOSÉ DE NEBRA

1. “A 4"." [Cuatro]: "Ni Marte con iras".

SSST, v1, acompto. 1b, Fa, C.
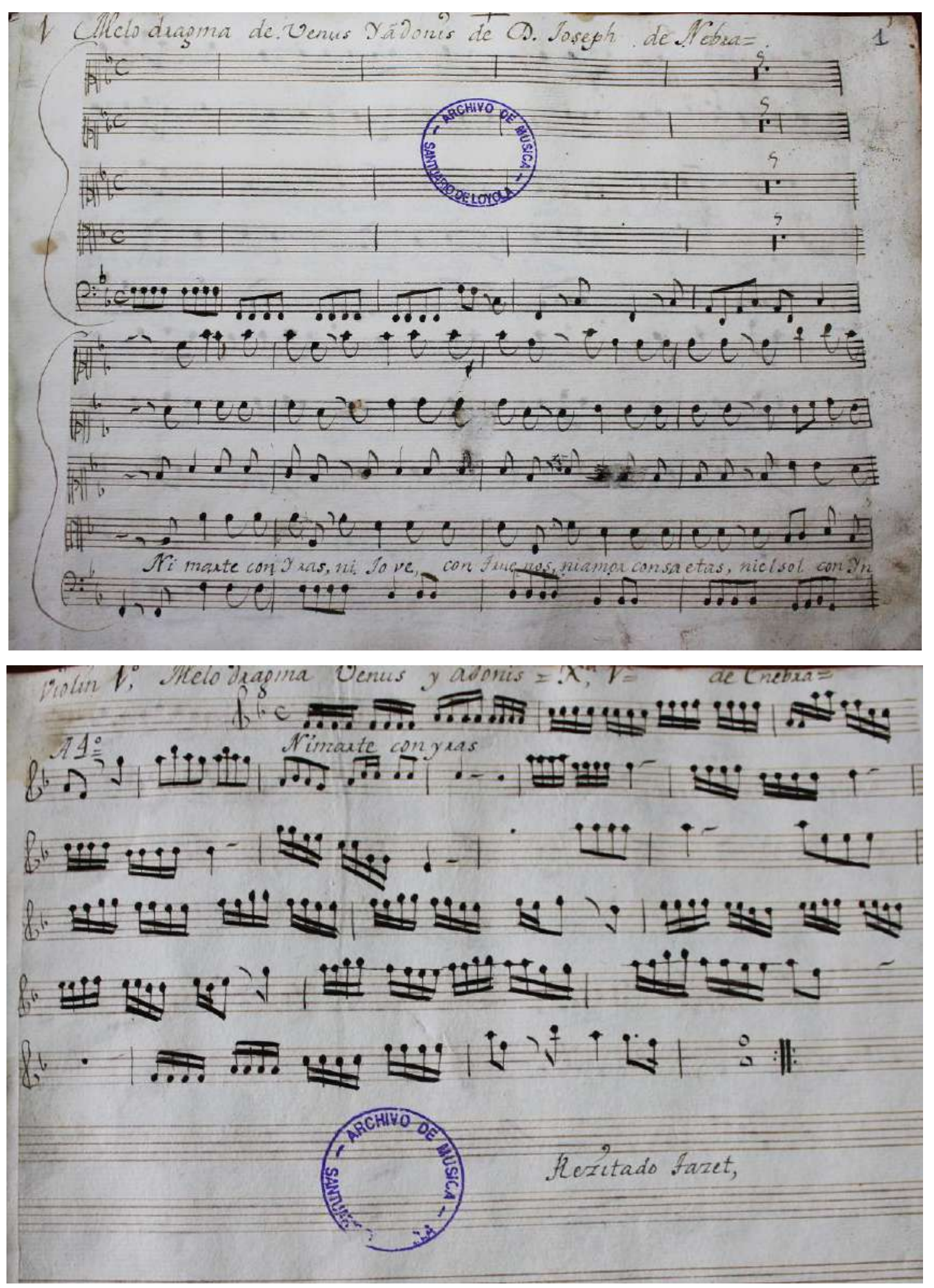

corresponden al cuaderno de voces y continuo y, en los casos en que hay otras partes instrumentales, al de violín 1 , por ese orden. 


\section{LUIS ANTONIO GONZÁLEZ MARÍN}

2. "Rezitado Venus": "Qué escucho, airados cielos".

S, acompto. 0, Re-Mi, C.

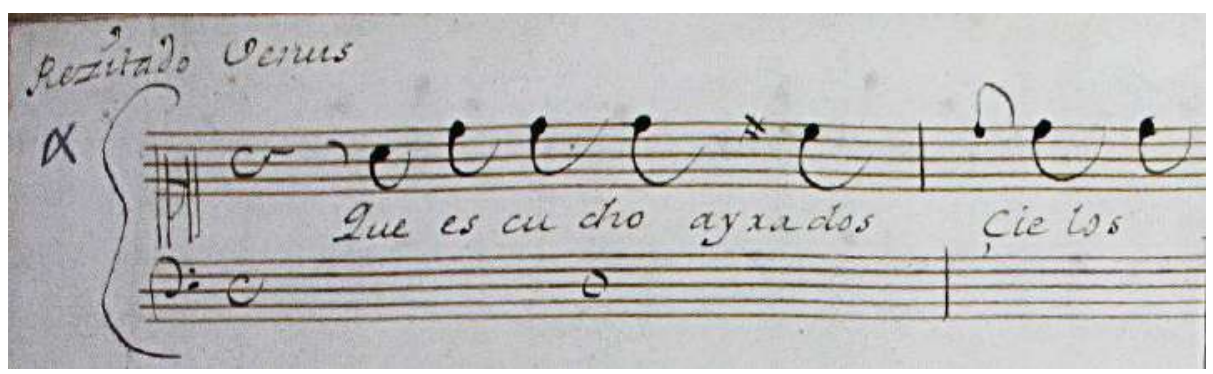

3. "Aria All[egr] $]^{\circ}="$ [Venus]: "Mi airada venganza".

S, v 1, acompto. 3\#, La, C.
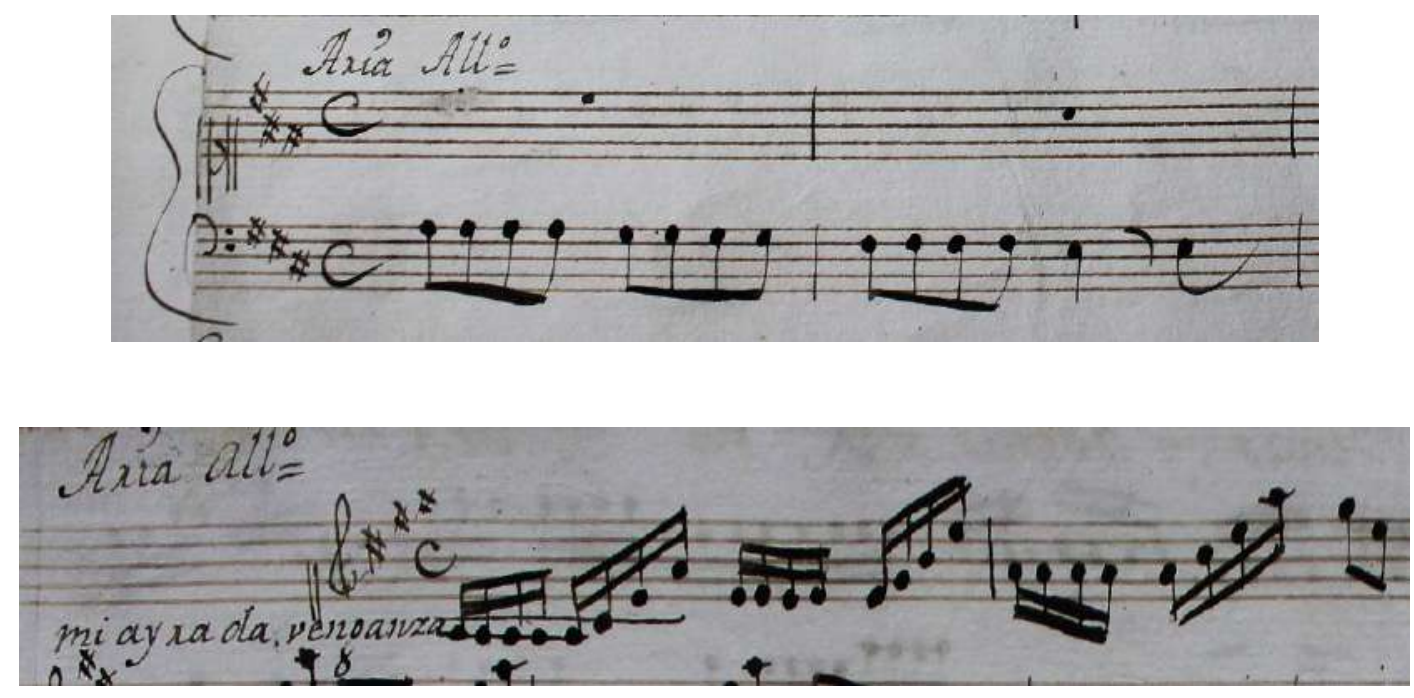

4. "Rez[ita]do Marte=": "Cese, cese el que miedo de la tierra".

S, acompto. 0, Re-Si, C.

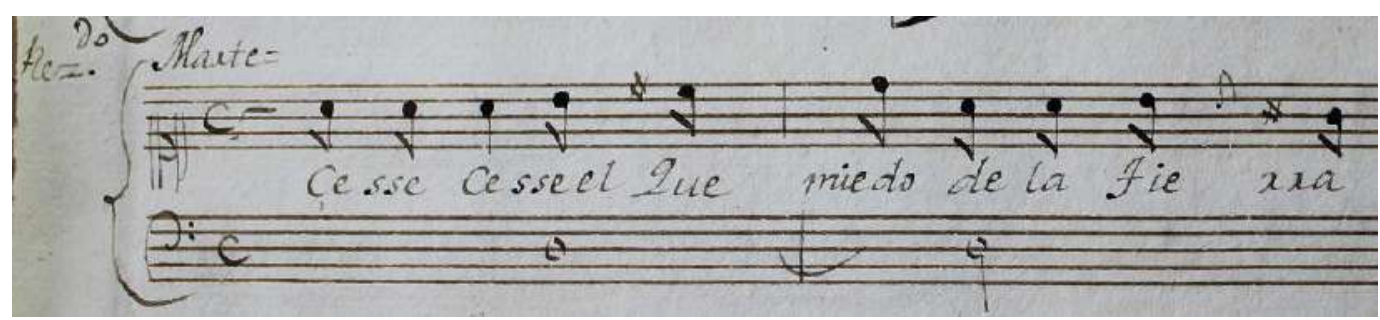




\section{ACERCA DE LA RECUPERACIÓN DE VENUS Y ADONIS, DE JOSÉ DE NEBRA}

5. "Aria Medio ayre” [Marte]: "Tú, suspensa beldad soberana”.

S, v1, acompto. 1\#, Mi, 3/4.
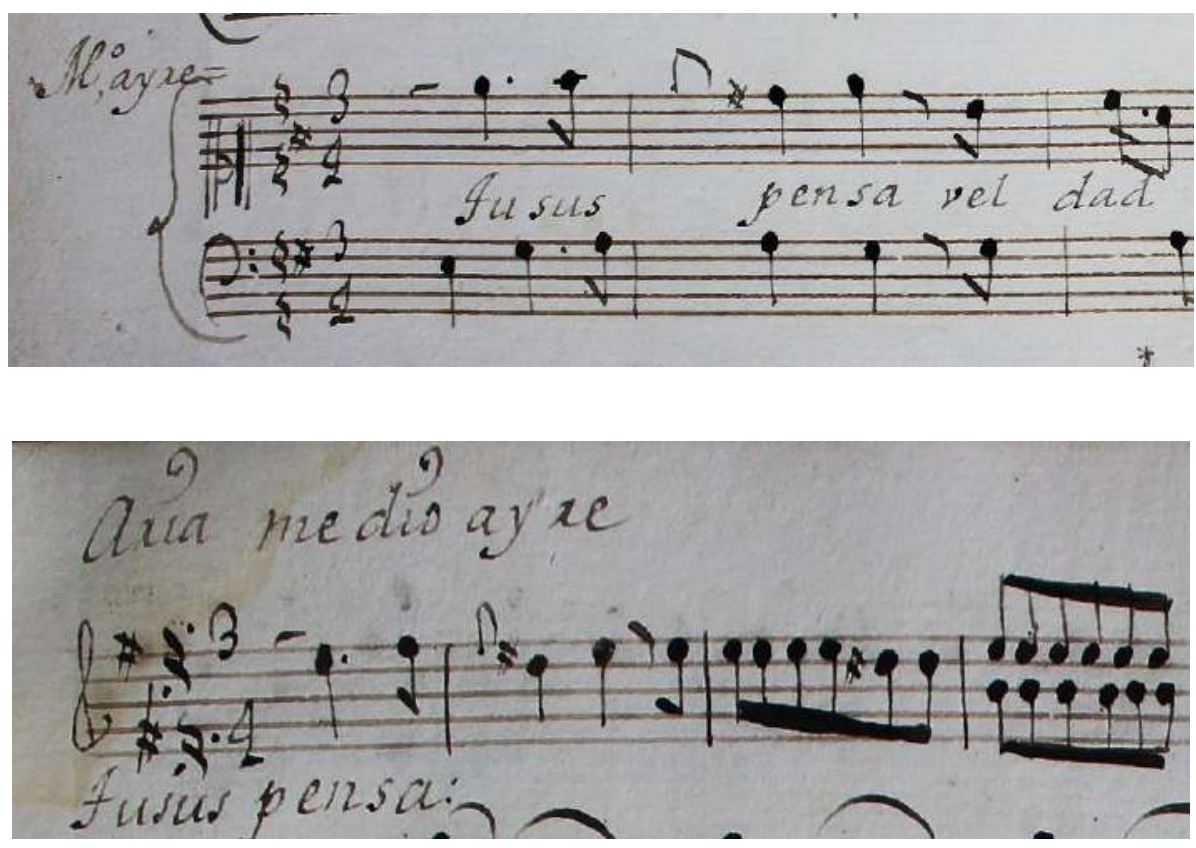

6. "Rez[ita]do" [Marte, Venus, Celfa y Clarín]: "Por qué lloras, bien mío".

SSSS, acompto. 0, Do-Fa, C.

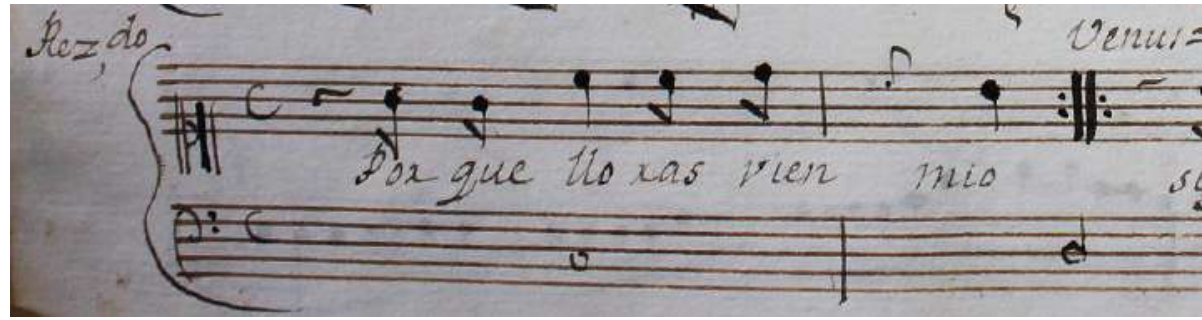

7. [Cuatro]: "Ni Marte con iras".

Repetición del número 1.

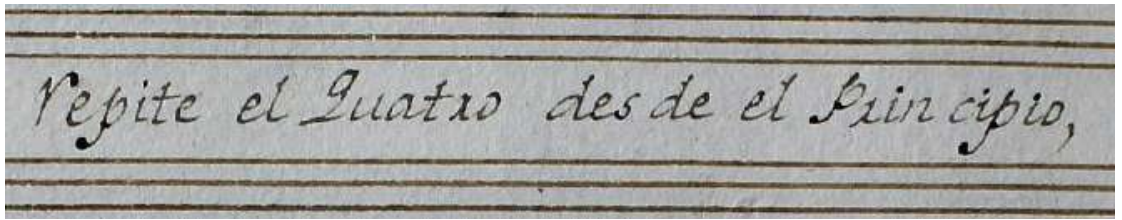




\section{LUIS ANTONIO GONZÁLEZ MARÍN}

8. "Rez[ita]do Venus" [y Marte]: "Estás ya noticioso".

SS, acompto. 0 Re-Sol, C.

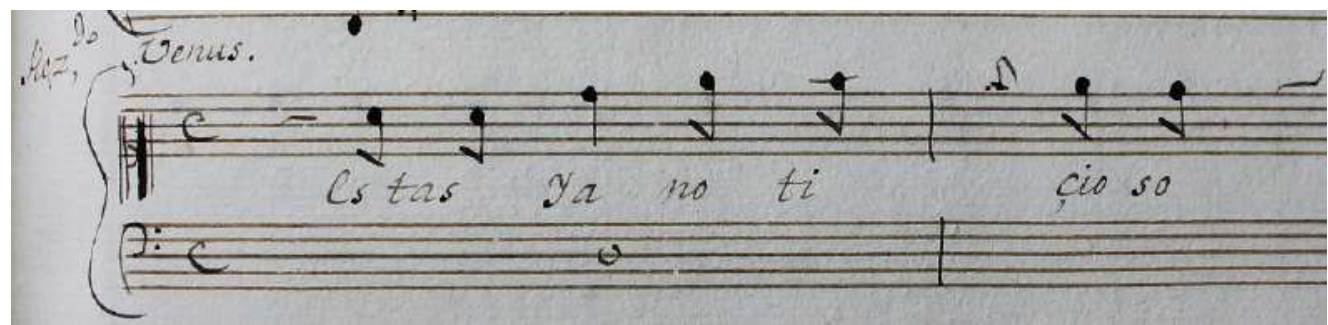

9. "Aria a duo All[egr]o", "Aria a duo / Marte / Venus": "Pues al estrago / A la furia". SS, v1, compto. 1\#, Sol, 3/8.
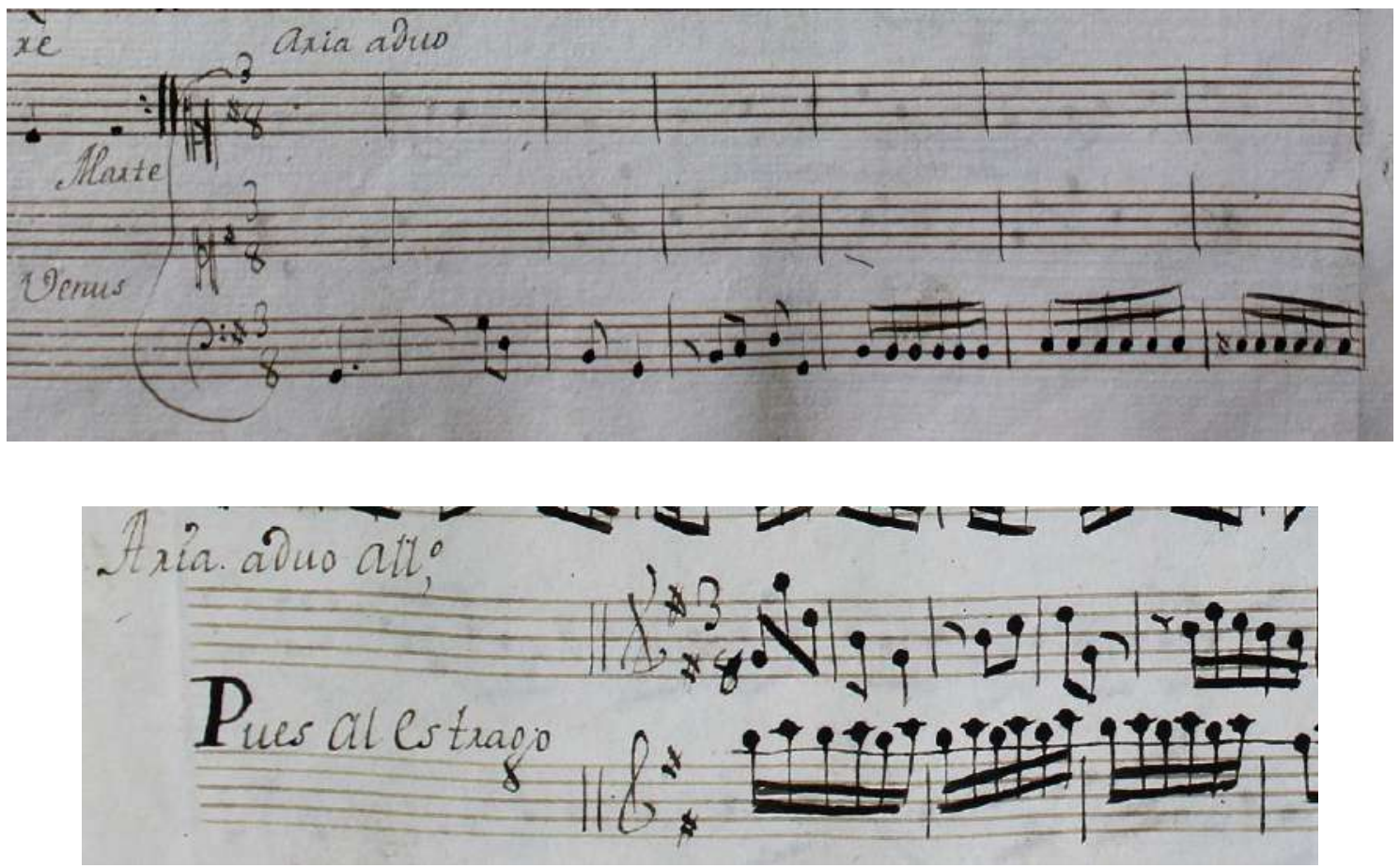

10. "Rez[ita]do Clarín" [y Celfa]: "Dígame usted, ninfilla mondonguera"-

SS, acompto. 0, Mi-Sol, C.

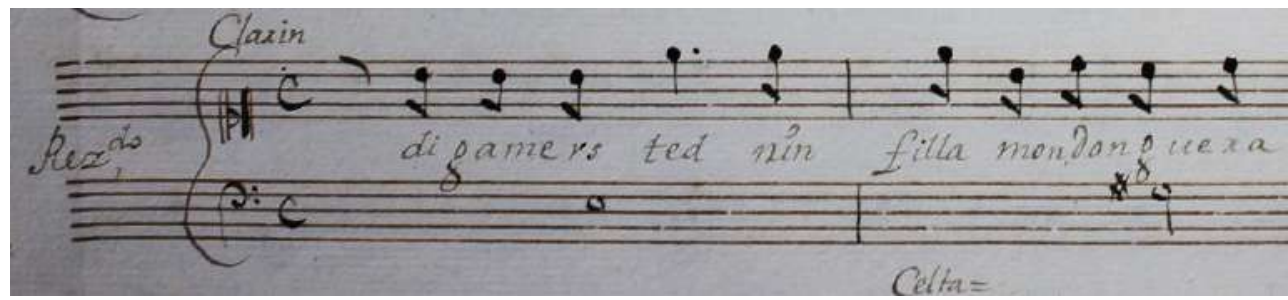


11. [Recitado Clarín]: "Por Dios que dice bien".

S, acompto. 0, Sol, C.

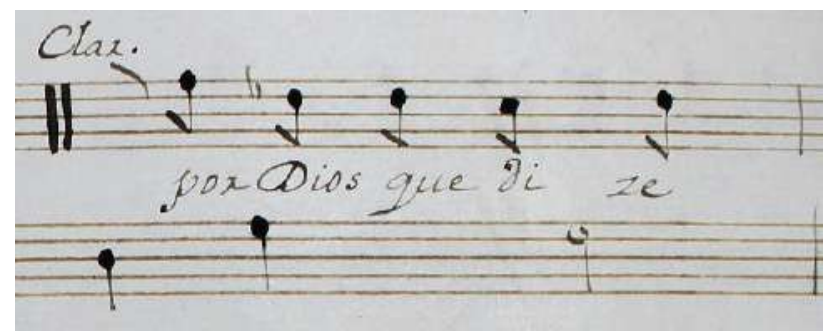

12. [Recitado Adonis y Clarín]: "Clarín amigo".

SS, acompto. 0, Sol-Sib, C.

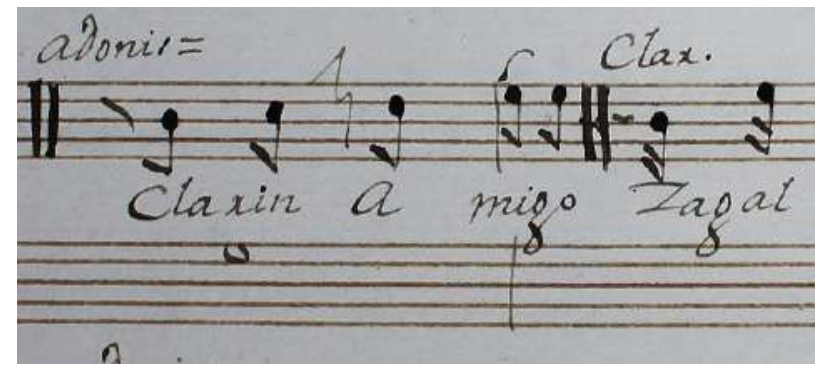

13. "Aria Vivo=" [Clarín]: "Por ver un conejo".

S, v1, acompto. 2b, Sib, 6/8.
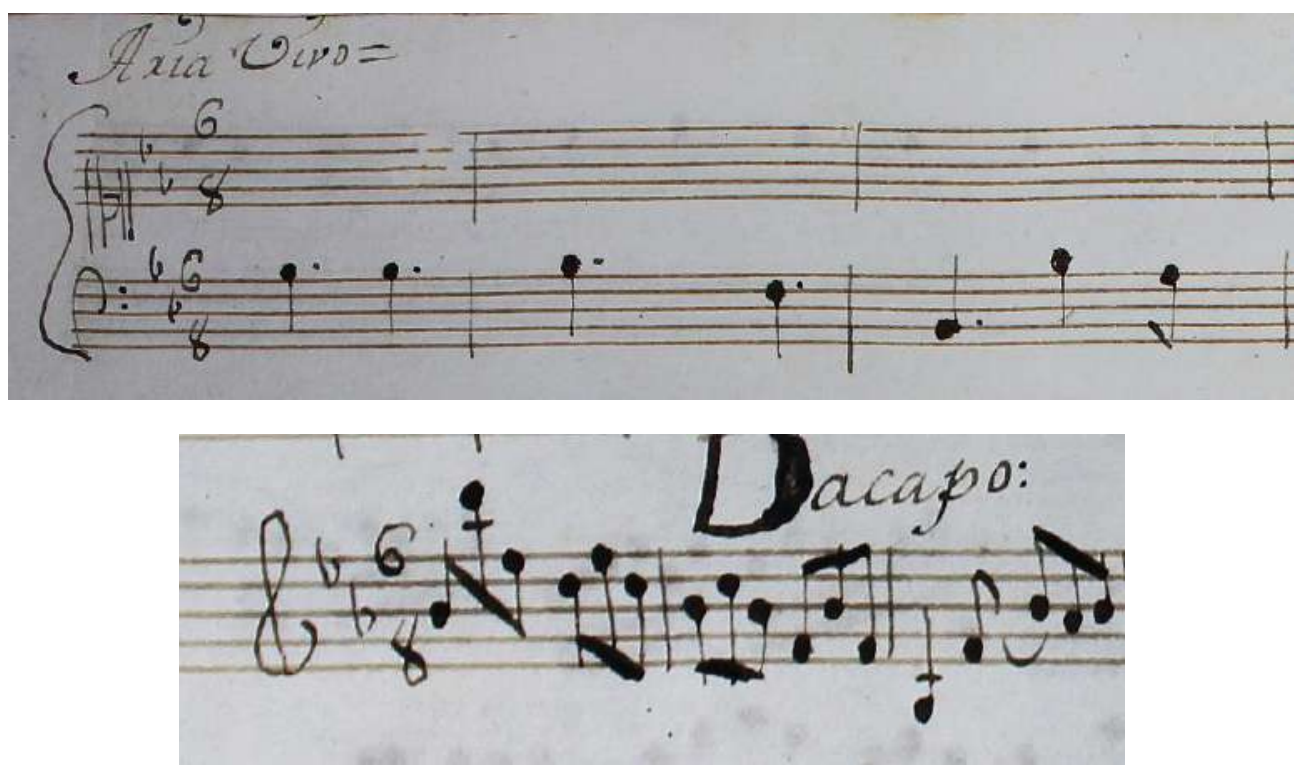


\section{LUIS ANTONIO GONZÁLEZ MARÍN}

14. "Rez[ita]do Adonis": "Oh cuánto engaña el ocio y el sosiego".

S, acompto. 0, Fa\#-Sol, C.

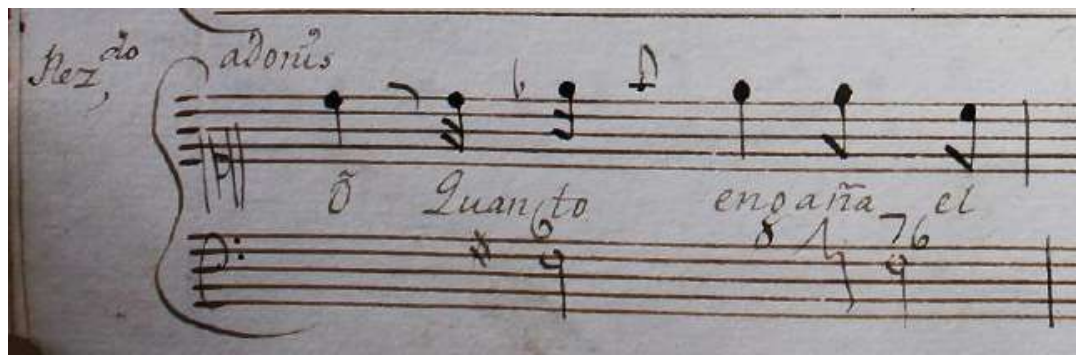

15. [Recitado Venus]: "Desde un coto a otro coto".

S, acompto. 0, Mib-La, C.

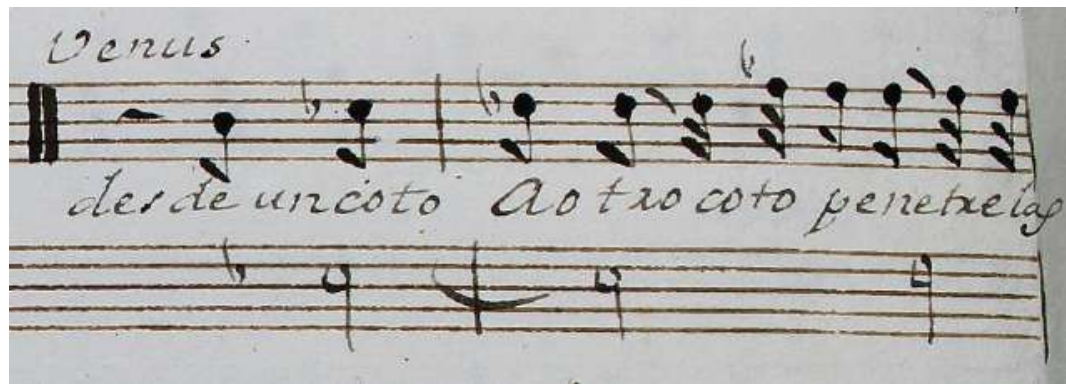

16. [Aria] "Adonis" "medio ayre con sordinas": "Ay Venus bella".

S, v1 [con sordina], acompto. 0, La, 2/4.

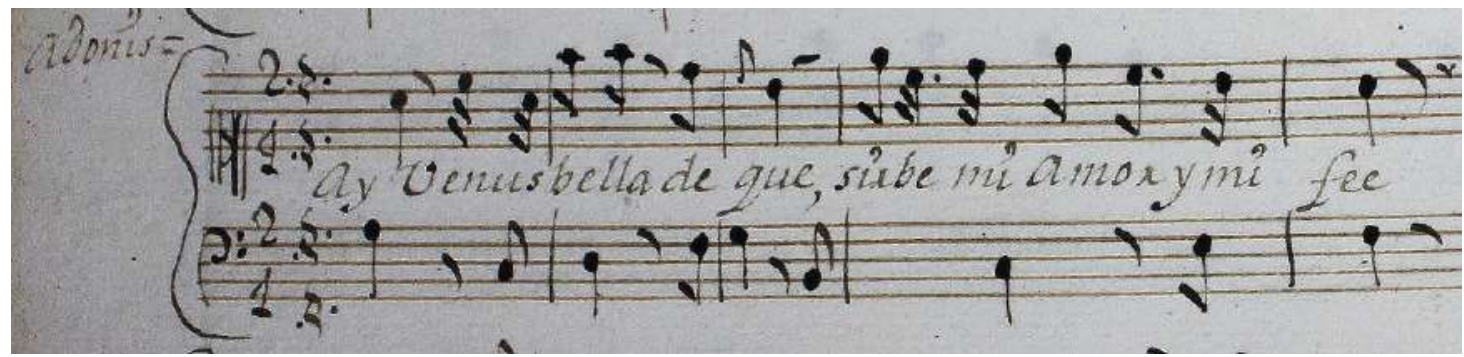

medio ayxe con. sox Dinas

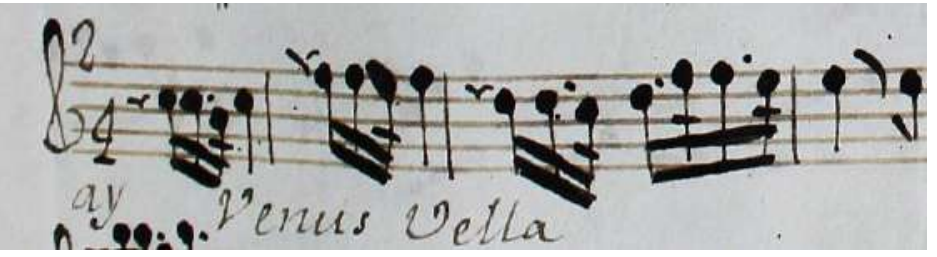




\section{ACERCA de LA RECUPERACIÓN DE VENUS Y ADONIS, DE JOSÉ DE NEBRA}

17. "Rezi[ta]do / Adonis" [y Venus]: "Espera, aguarda, hermosa ingrata mía".

S, acompto. 0, Re-Do, C.

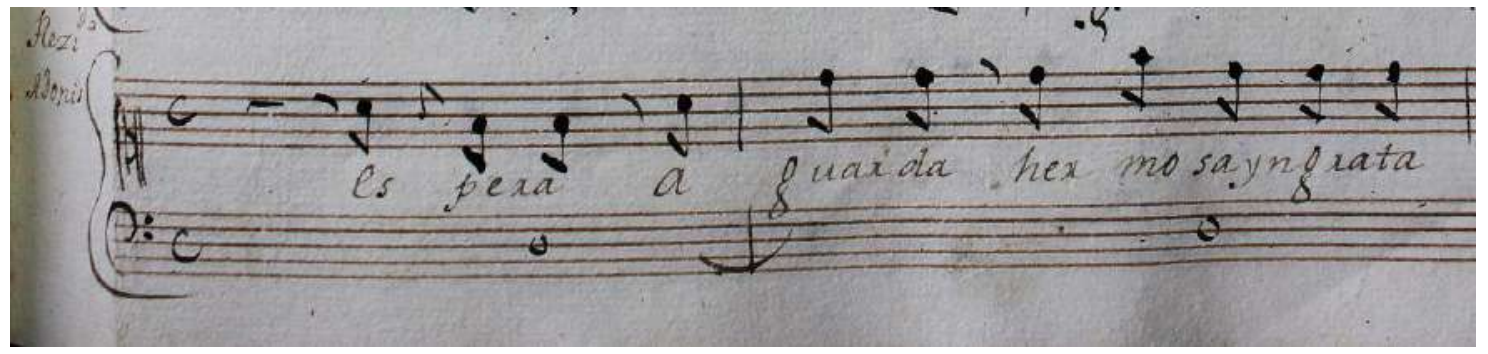

18. "All[egr]o, Aria con trompas" [Venus]: "Trompas venatorias".

S, [trompas], v1, acompto. 1b, Fa, C.
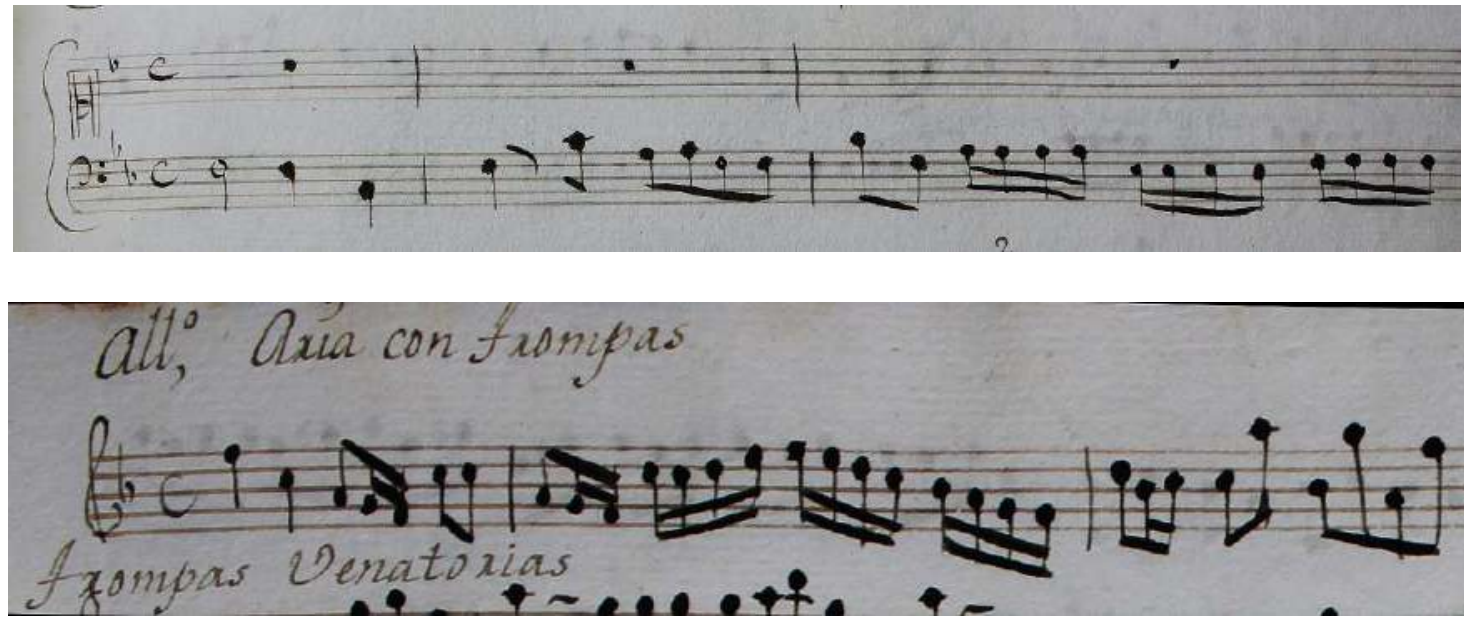

19. "Rezitado Adonis": "Así te vas, lisonja del sentido".

S, acompto. 0, Re-Re, C.

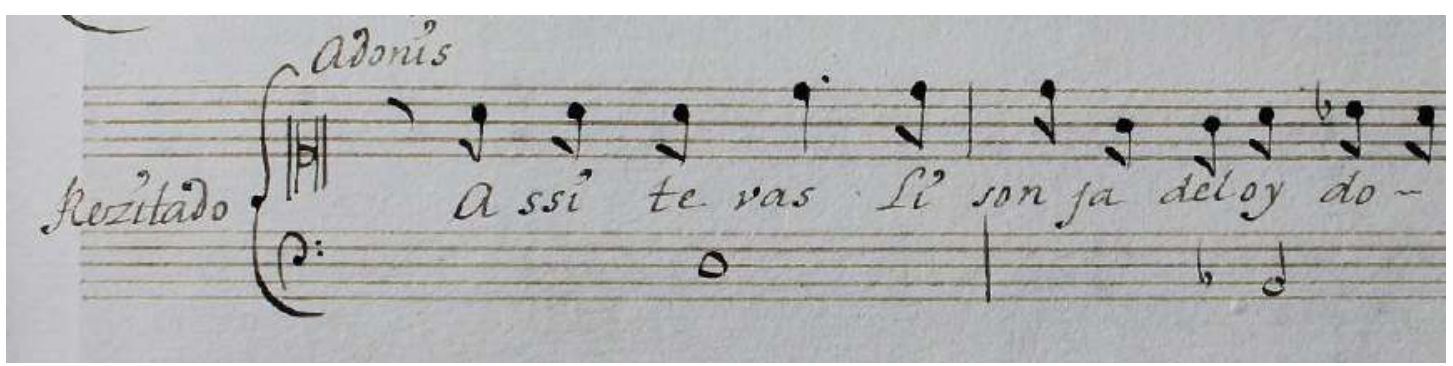




\section{LUIS ANTONIO GONZÁLEZ MARÍN}

20. "Aria Adonis] Vivo": "Bate la navecilla".

S, v1, acompto. 1\#, Sol, 6/8.
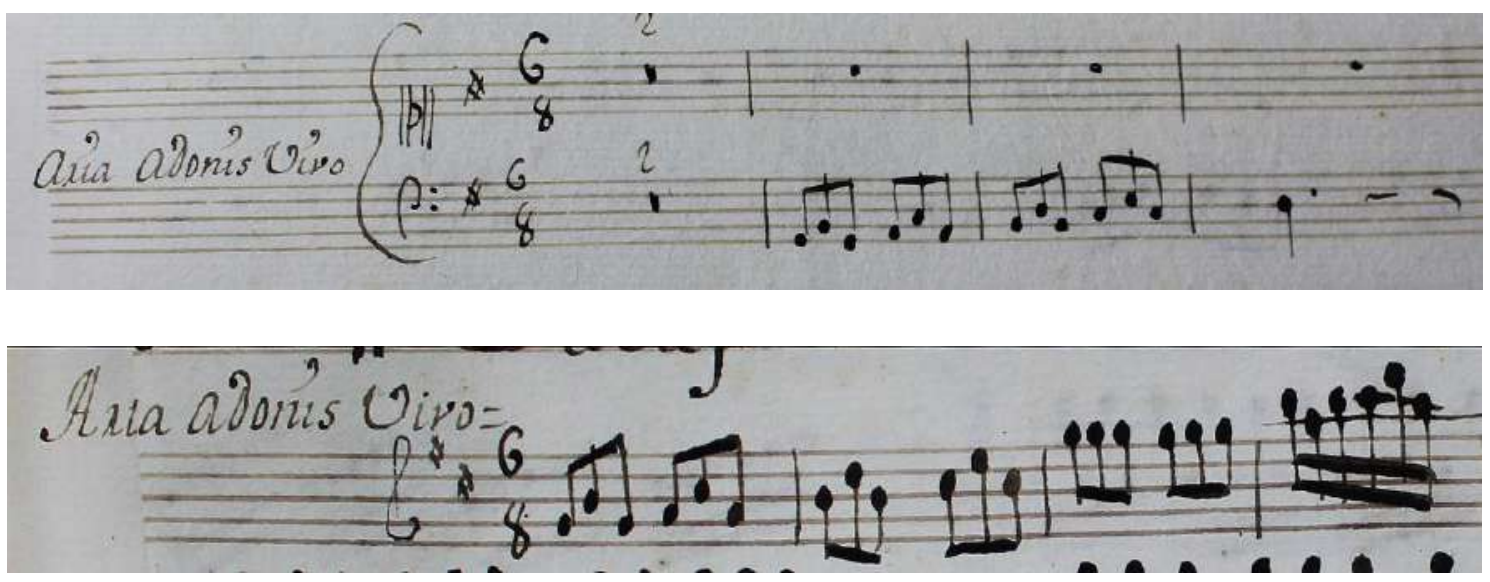

21. "Rez[ita]do Çelfa": "Con efecto Clarín me galantea".

S, acompto. 0, Do-La, C.

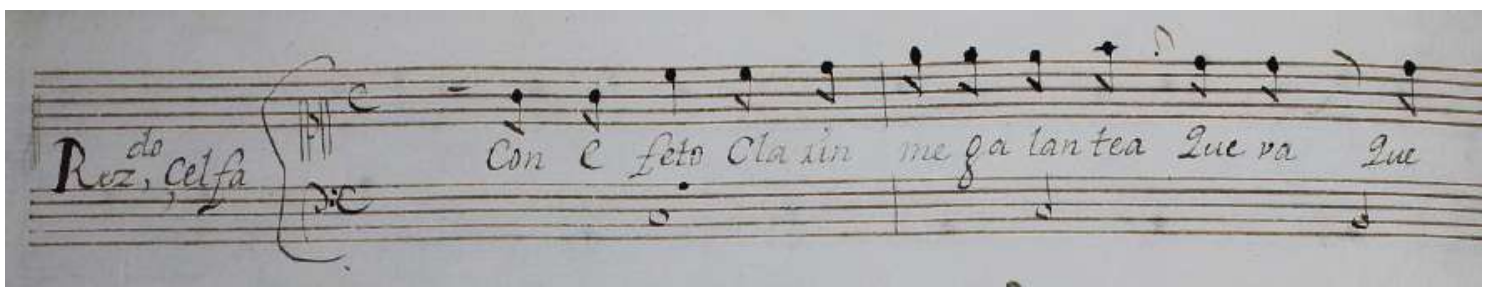

22. "Aria Vivo" [Celfa]: "Cualquiera mozuela"-

S, v1, acompto. 0, La, $3 / 4$.
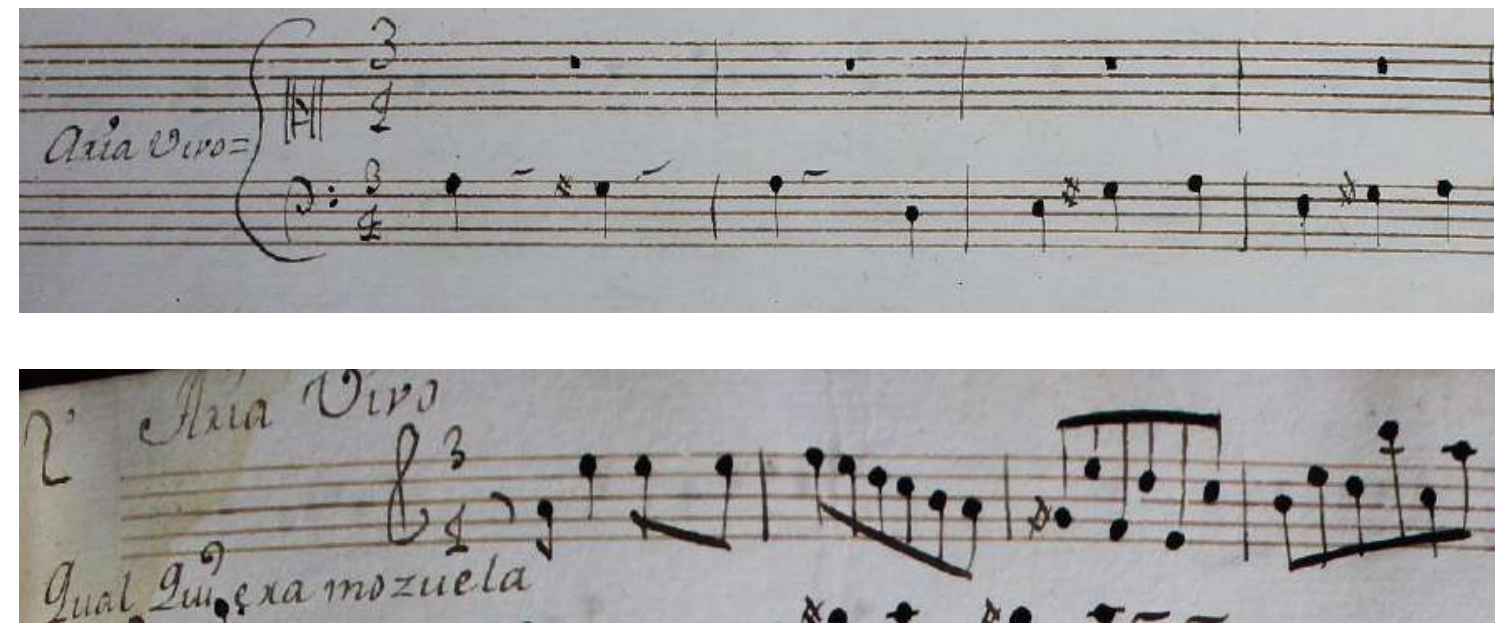


\section{ACERCA DE LA RECUPERACIÓN DE VENUS Y ADONIS, DE JOSÉ DE NEBRA}

23. "Rez[ita]do Marte [Uno, Otro, Cibeles y Voces dentro]: "Ah de esa triste boca" SSSSST, acompto. 0 Do-Do, C.

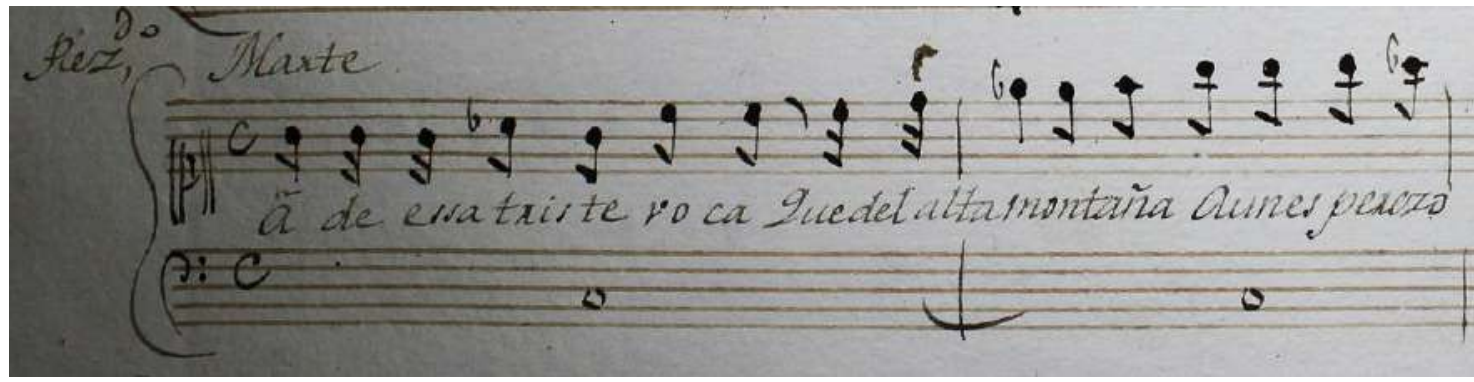

24. "Vivo= / Aria Ziveles=": "Ya de la nube de la montaña".

S, v1, acompto. 0, Do, C.
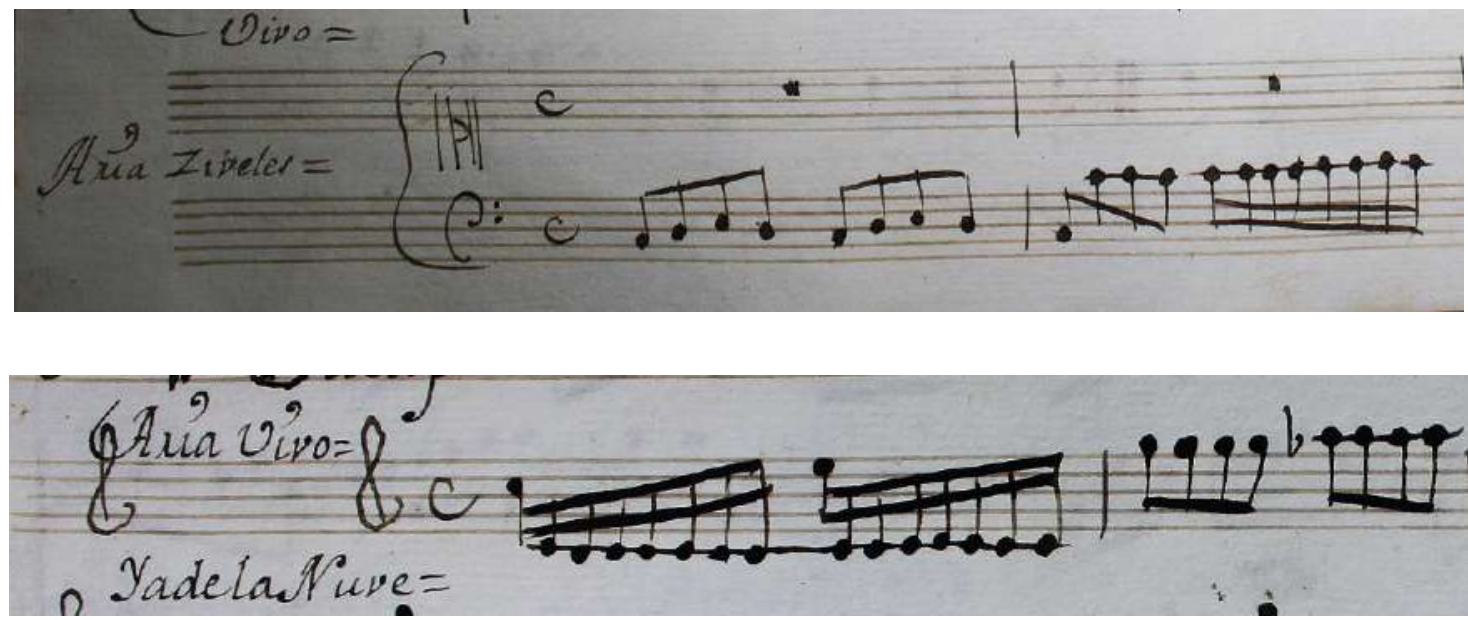

25. "Rez[ita]do Vozes" [y Marte]: "Guarda la fiera".

SSSS, acompto. 0, Do-Fa, C.

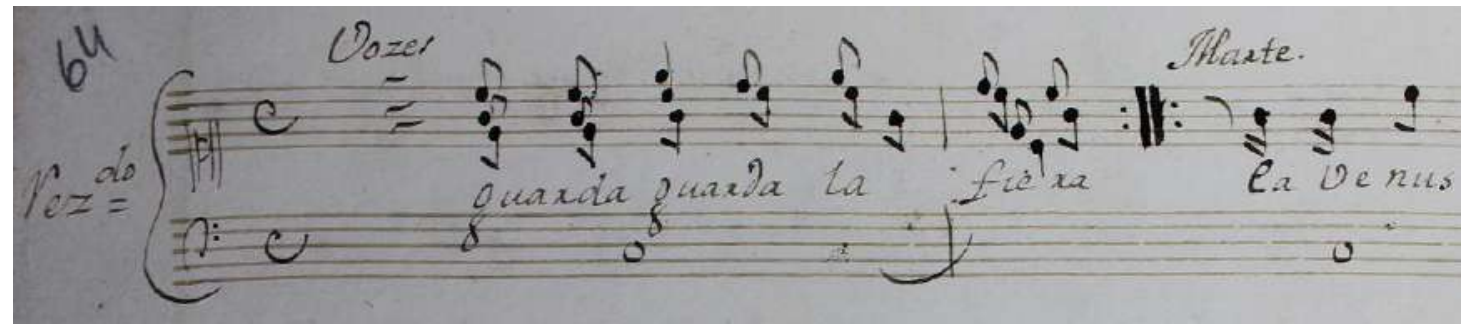




\section{LUIS ANTONIO GONZÁLEZ MARÍN}

26. [Recitado Adonis, Venus, Clarín y Celfa]: "Yo el primero seré que mi venablo". SSSS, acompto. 0, Re-Re, C.

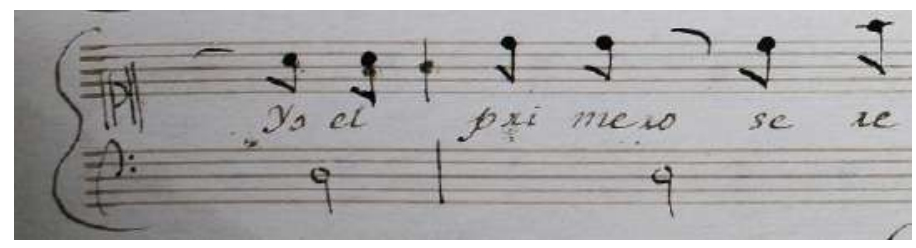

27. "Aria de Clarín Vivo”, “Aria con clarín” [Adonis]: "Silbo del aire veloz”.

S, [clarín], v1, acompto. 2\#, Re, C.
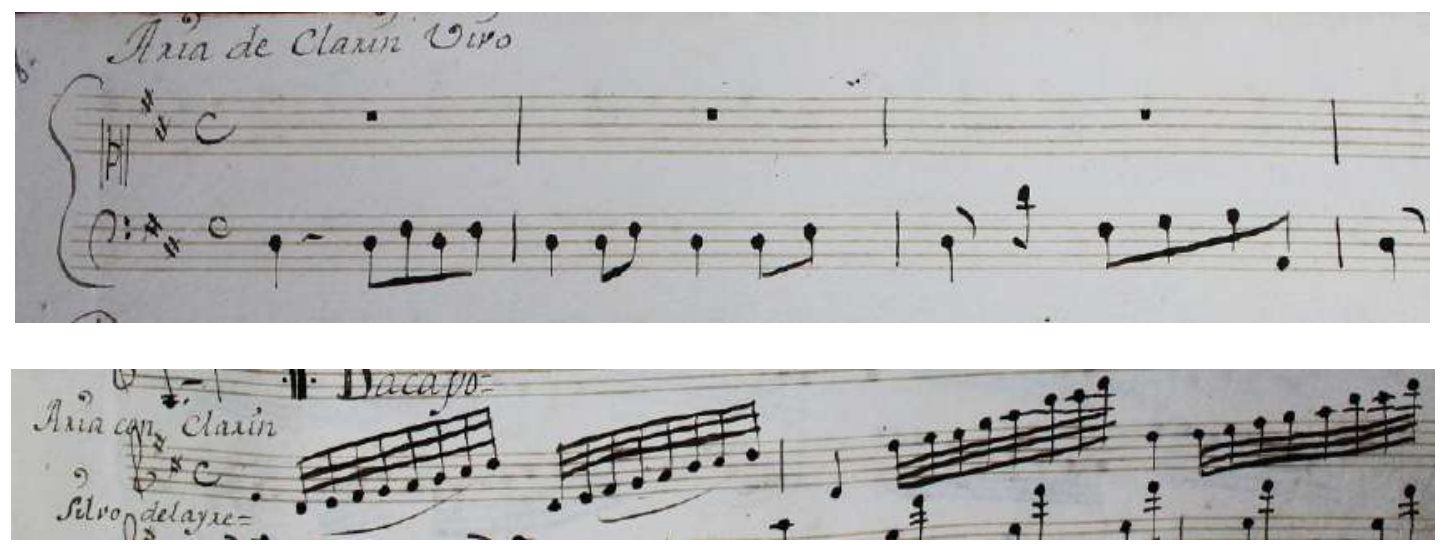

28. "Rez[ita]do Venus" [y Voces dentro, Clarín y Celfa]: “Ay de mí, que es en vano”. SSSSST, acompto. 0, Sol-Fa, C.

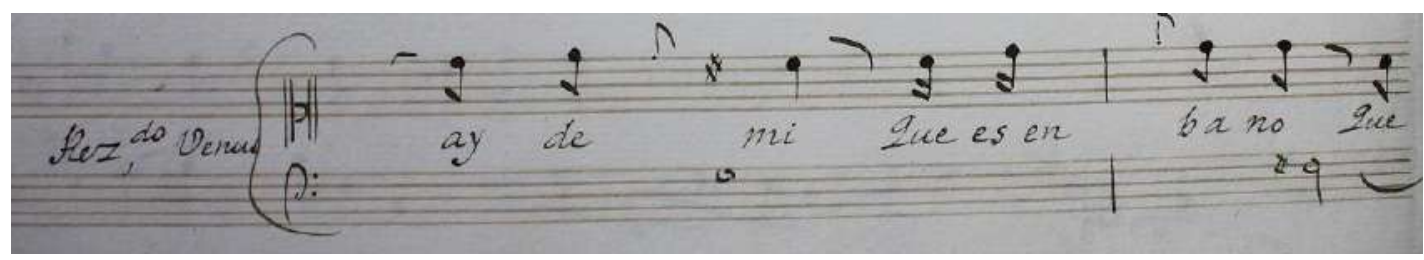

29. [Recitado Clarín y Celfa]: "El picarón ladrón que tal hiciera".

SS, acompto. 0, Fa-Do, C.

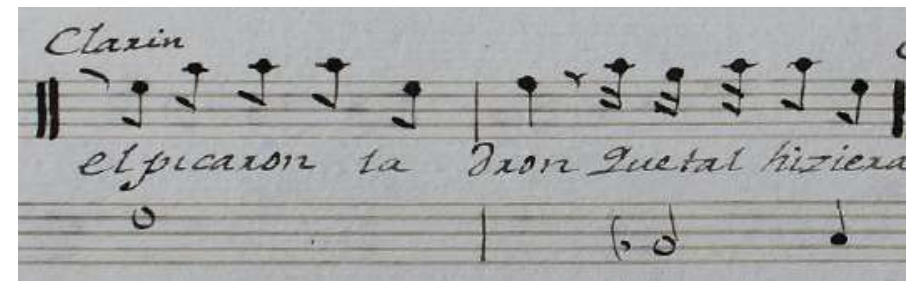




\section{ACERCA DE LA RECUPERACIÓN DE VENUS Y ADONIS, DE JOSÉ DE NEBRA}

30. "Aria a duo Ayroso" [Celfa y Clarín]: “Ay, mi bien, qué espanto".

SS, v1, acompto. 2b, Do, 3/4.
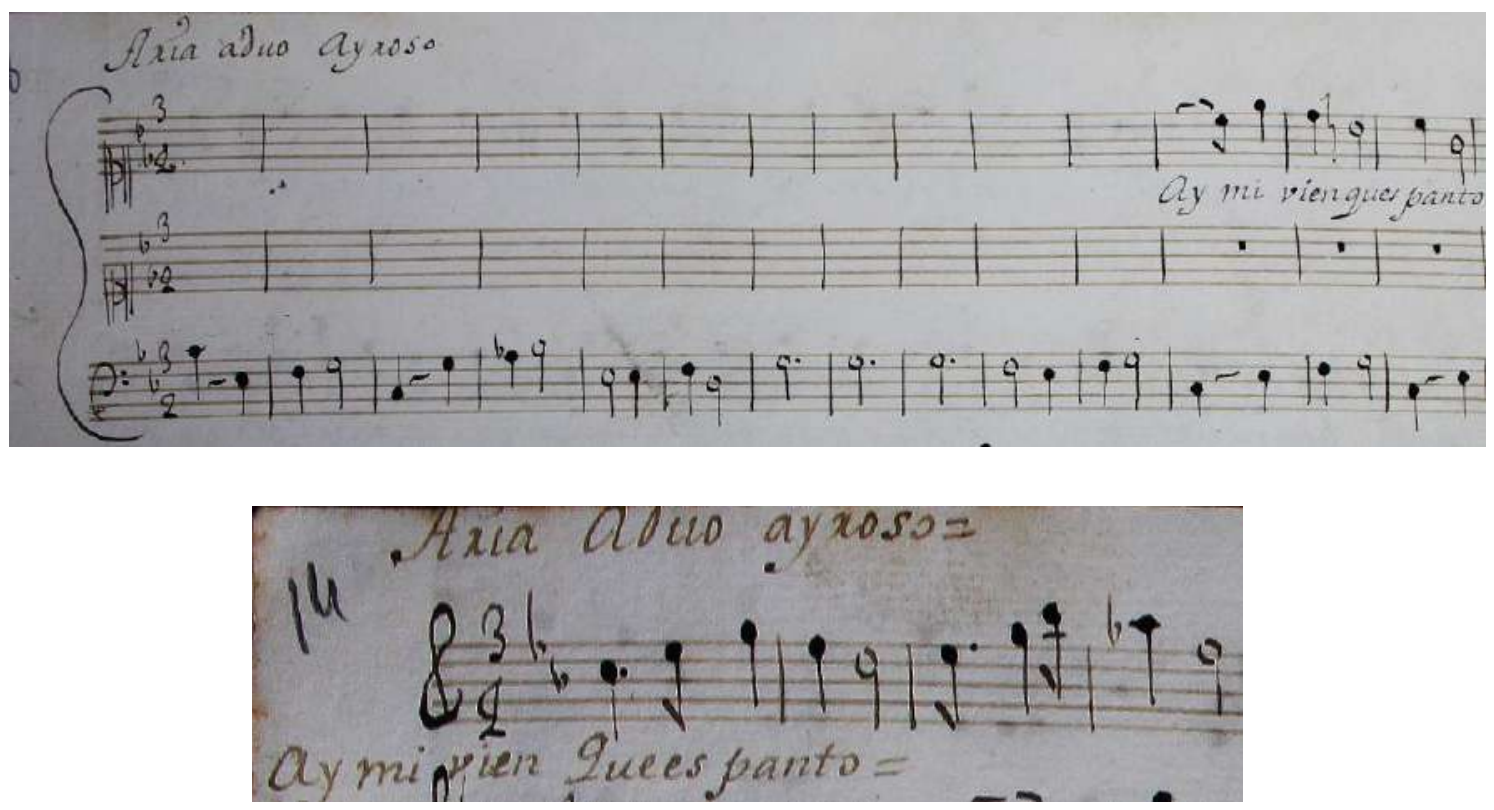

31. "Rez[ita]do Marte": "Ea, airada inclemencia".

S, acompto. 0, Fa-Sib, C.

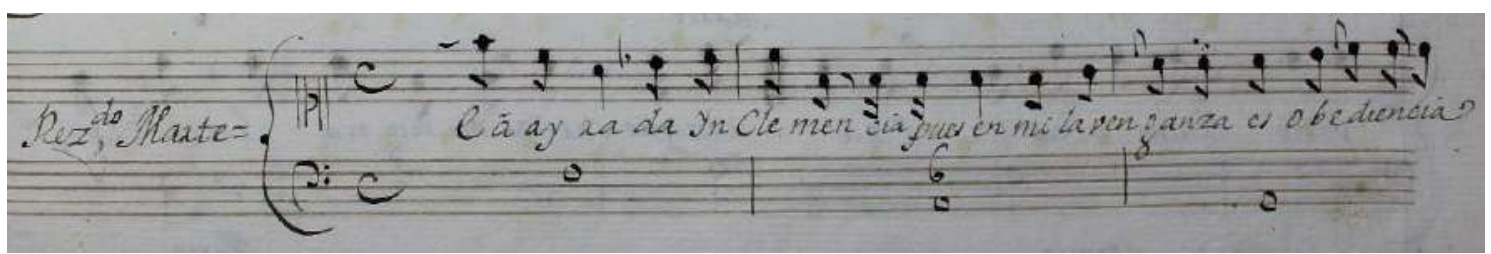

32. [Recitado Venus y Marte]: "Marte / Venus divina".

SS, acompto. 0, Sib-Sol, C.

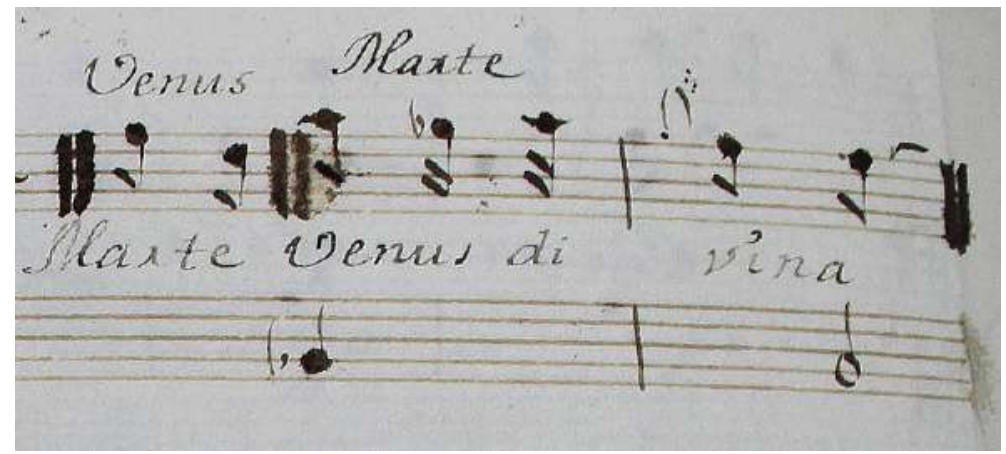




\section{LUIS ANTONIO GONZÁLEZ MARÍN}

33. "All[egr]o / Aria con trompas de caza", "Aria con tronpas Vivo" [Marte]: "Tan vano es pretender".

S, [tompas], v1, acompto. 1\#, Sol, 6/8.
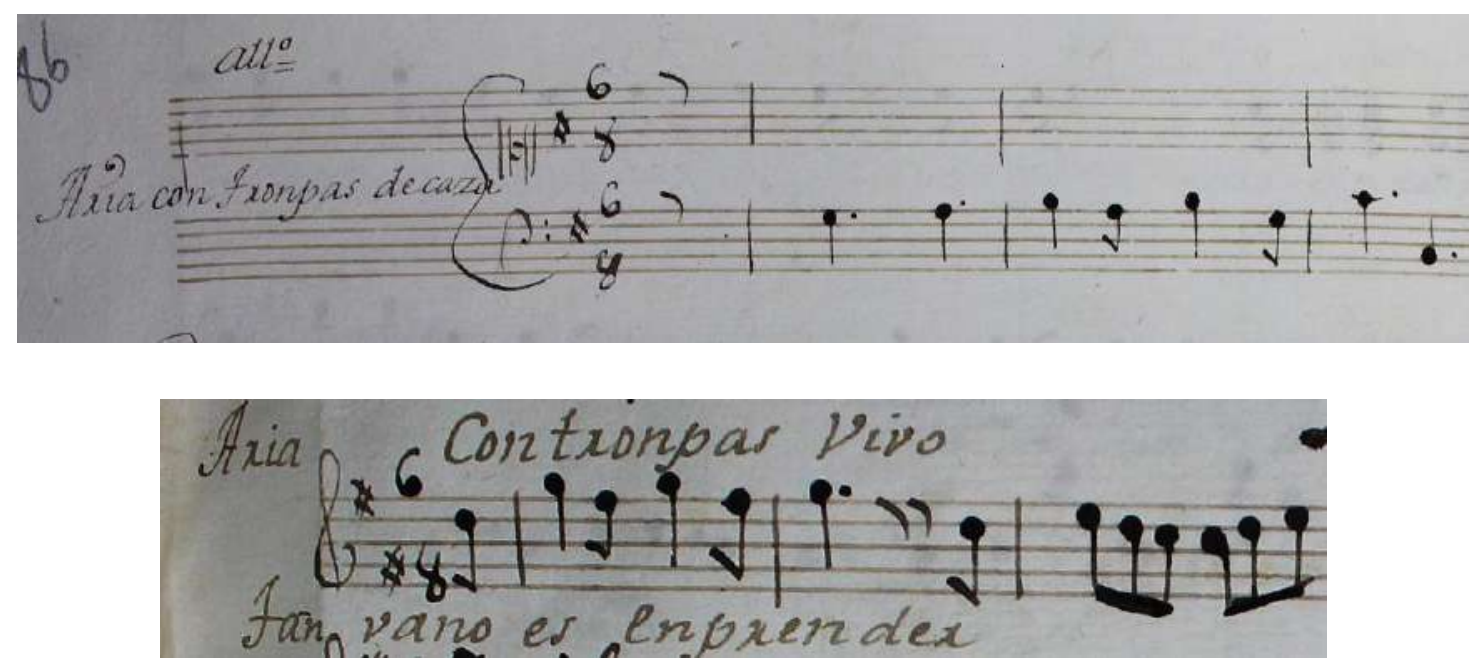

34. "Rez[ita]do Venus" [y Voces dentro, Adonis y Clarín ]: "Espera, Marte, que quien eso influye"

SSSSSS, acompto. 0, Mi-Re, C.

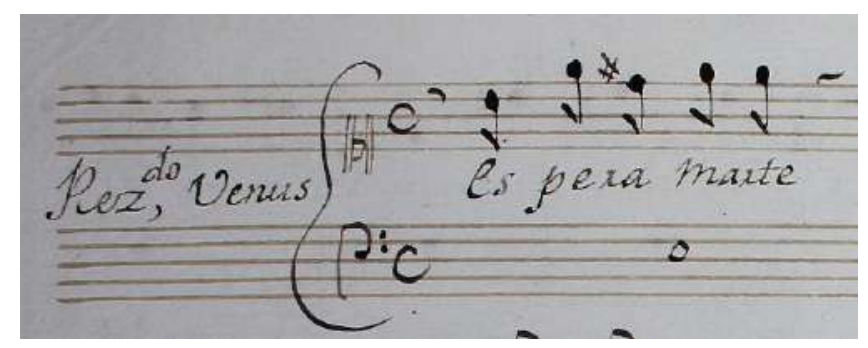

35. [Recitado Venus y Adonis]: "Qué es esto, Adonis mío".

SS, acompto. 0, Re-Mib, C.

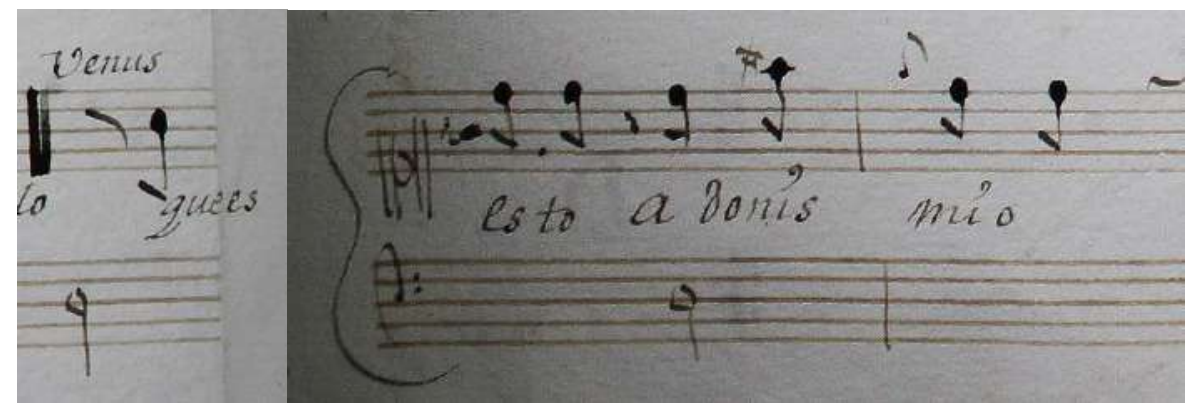




\section{ACERCA DE LA RECUPERACIÓN DE VENUS Y ADONIS, DE JOSÉ DE NEBRA}

36. "Violines punteado / Aria sin da Capo" [Adonis]: "Adiós, Venus bella".

S, v1 [punteado], acompto. 3b, Mib, $3 / 4$.
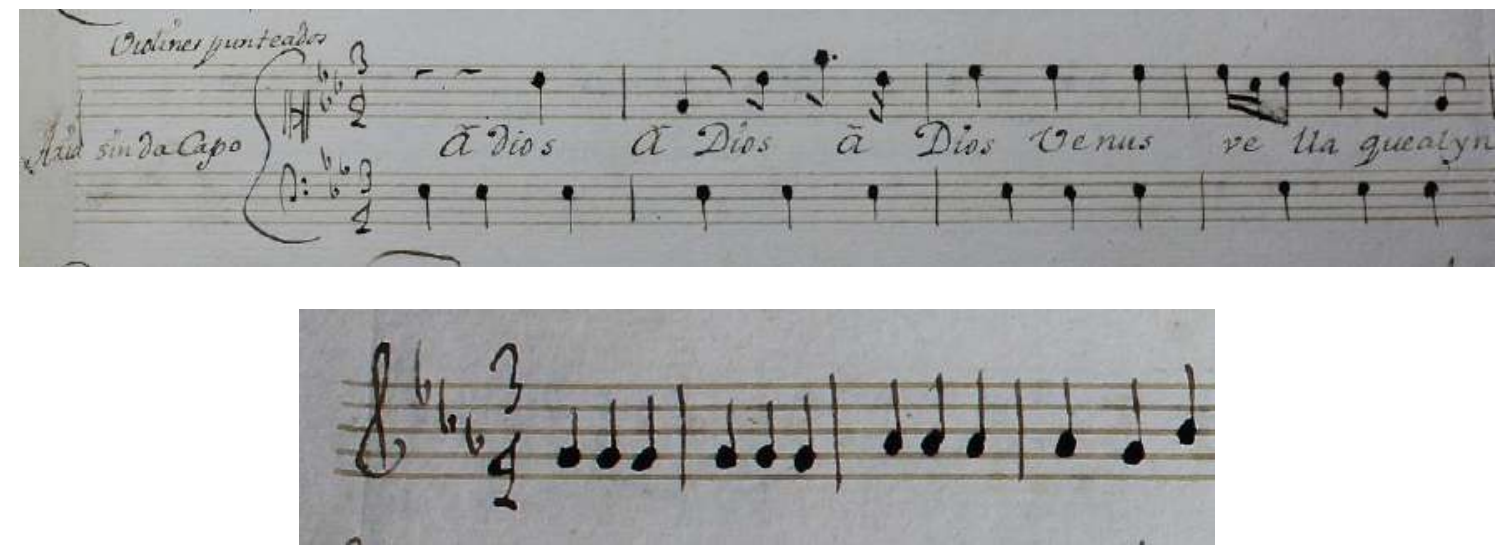

37. "Rezi[ta]do Venus": "No triunfa el hado".

S, acompto. 0 Do-Re, C.

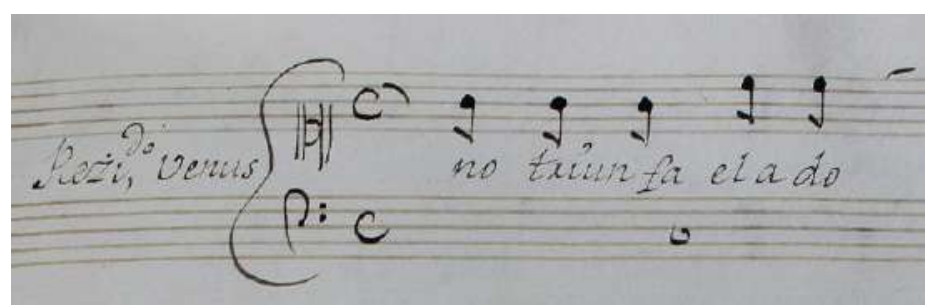

38. "Aria ayroso Venus": "En flor tu vida crezca".

S, v1, acompto. 0, Re, C.
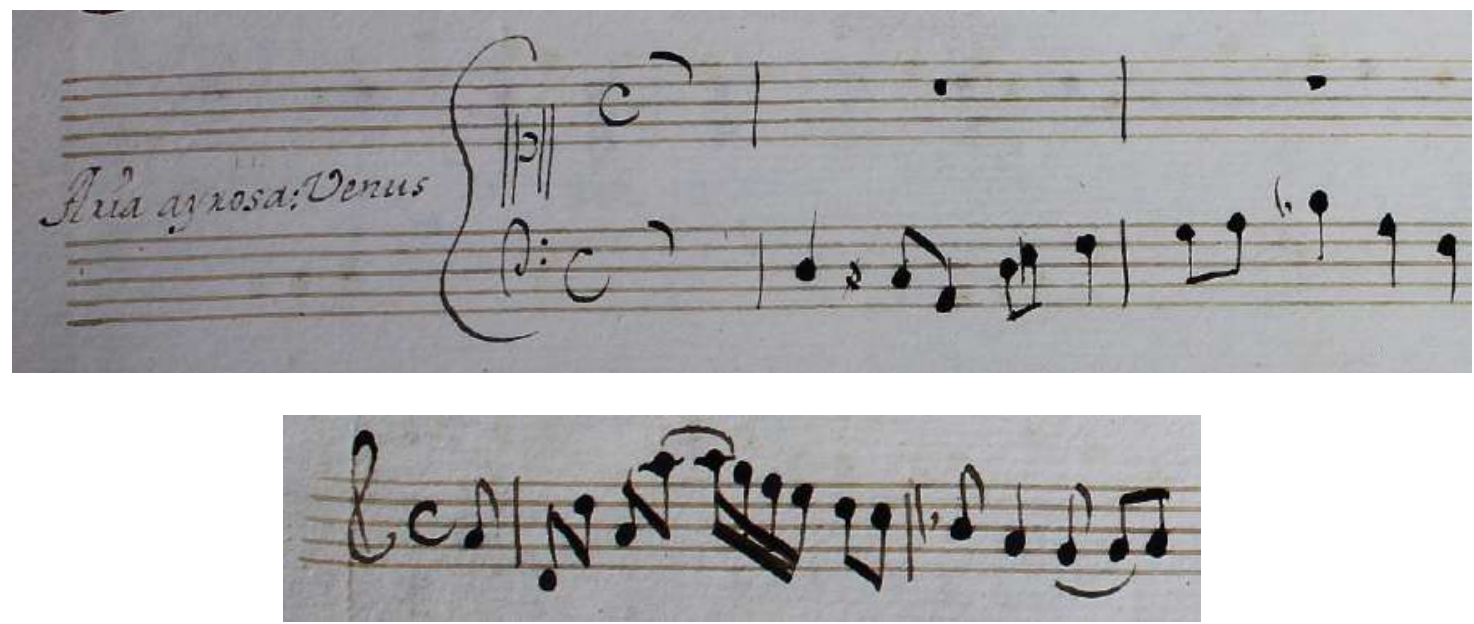


\section{LUIS ANTONIO GONZÁLEZ MARÍN}

39. "Rezitado Venus" [y Voces, Marte, Cibeles, Celfa, Clarín y Adonis]: “Ah de esos horizontes".

SSSSSS, acompto. 0, Re-Mi, C.

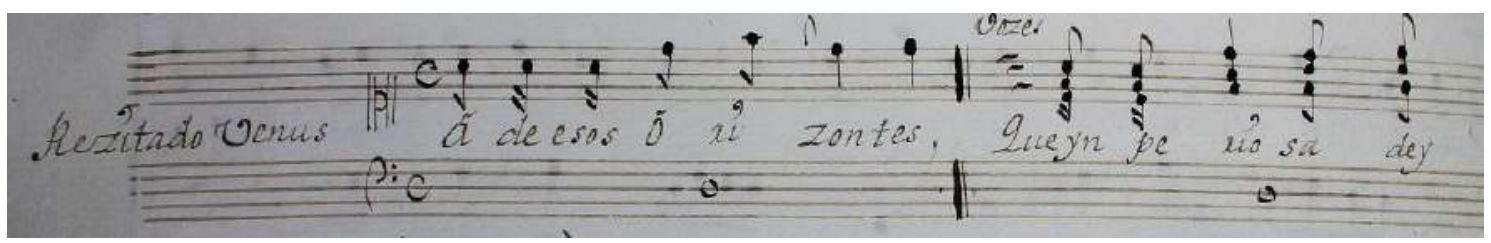

40. [Aria a] "Duo Venus y Adonis": "Amor solo / Solo Amor".

SS, v1, acompto. 3\#, La, 3/8.
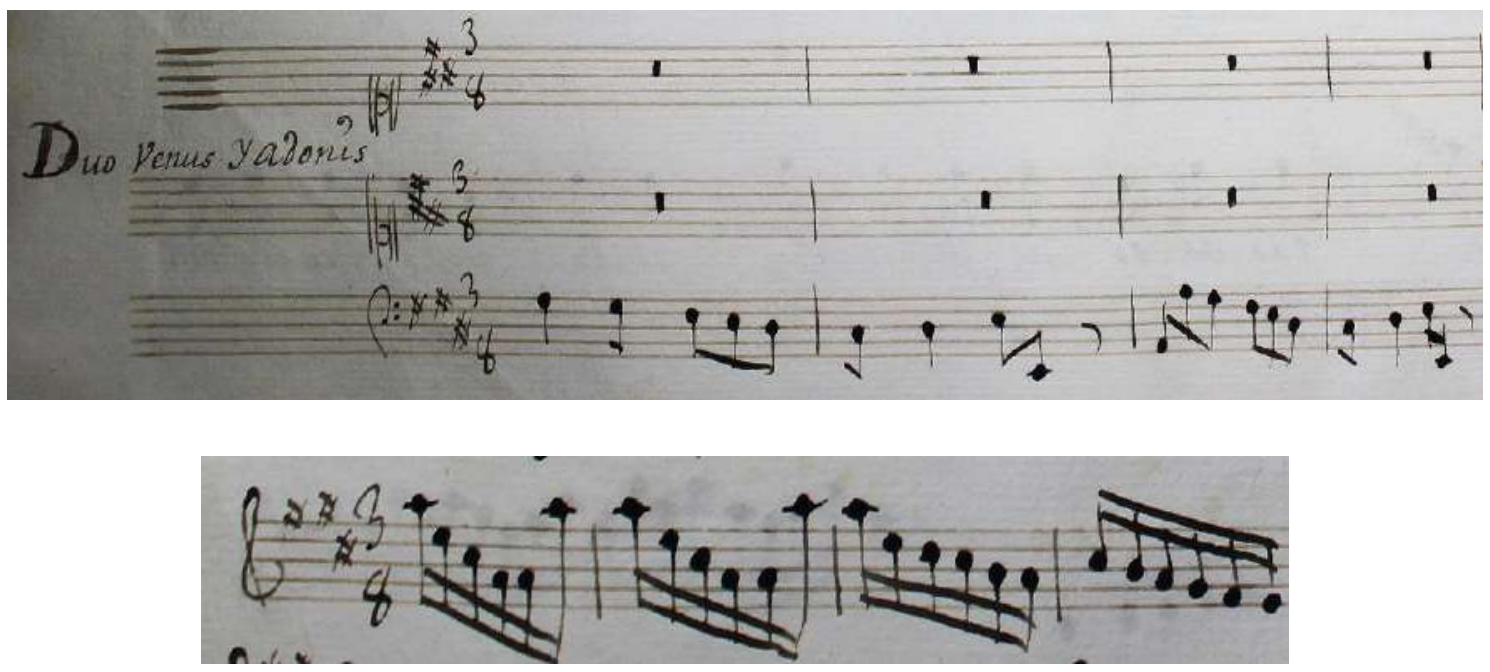

41. "Rez[ita]do Civeles" [y Celfa, Clarín, Venus, Marte y Adonis]: "Viva eterna de Venus la fineza".

SSSSSS, acompto. 0, La-Re, C.

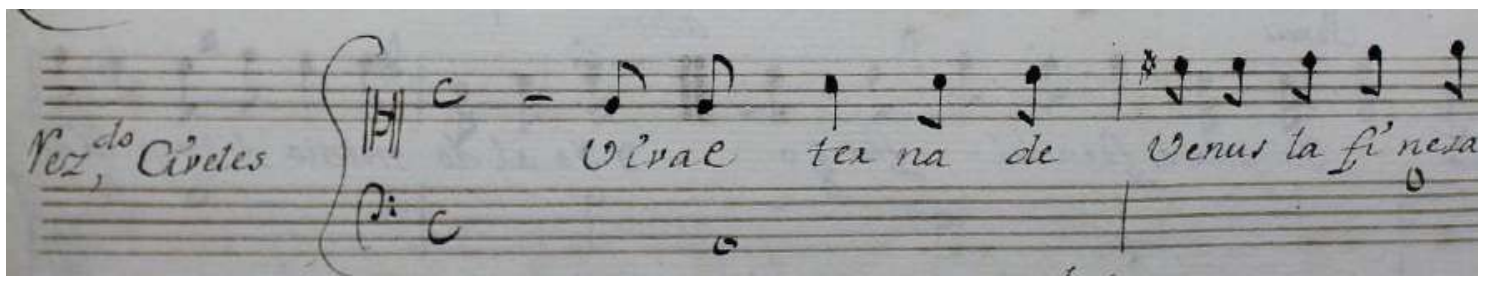




\section{ACERCA DE LA RECUPERACIÓN DE VENUS Y ADONIS, DE JOSÉ DE NEBRA}

42. [Cuatro]: "Victoria por el Amor".

SSST, v1, acompto. 2\#, Re, C.
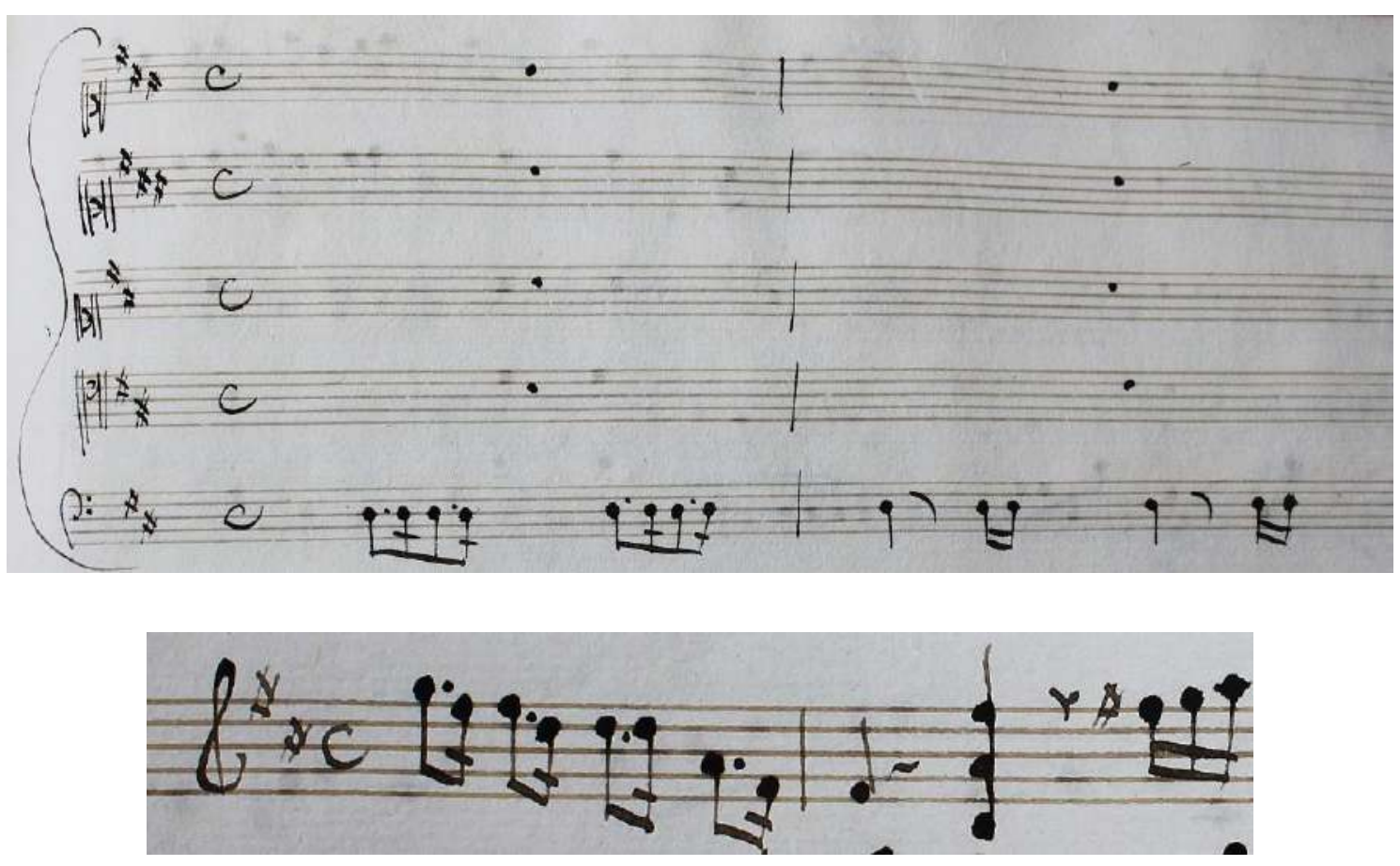

$* * *$

La fuente musical de Venus y Adonis suscita numerosas dudas y cuestiones. En primer lugar tenemos la fecha de copia y el nombre del copiante. El manuscrito que conocemos fue confeccionado en 1733, varios años después de la fecha de composición y estreno (1729) de la obra, tal vez teniendo a la vista alguna posible reposición. Puede aventurarse alguna hipótesis acerca de la identidad del copista, Antonio Palomino "el menor". Entre finales del siglo XVII y comienzos del XIX el apellido abunda entre gentes del teatro ${ }^{20}, \mathrm{y}$ hay constancia de una dinastía de comediantes a la que tal vez perteneció el copista de Venus y Adonis. Un Francisco Antonio Palomino -conocido como Mátalo todo- formaba parte de compañías teatrales itinerantes desde los años 80 del siglo XVII: se le ve en Lisboa en 1681, en Valencia en 1688, 1695, 1697, 1699 y 1701, y en Alicante en 1702. Tuvo una hija llamada Francisca Palomino, que casó con Vicente Julián Guerrero (padre de Manuel Guerrero, poseedor del único libreto de Venus y Adonis que hoy conocemos), y un hijo varón llamado Antonio, al que apodaron "por mal nombre Perneras" 21 . Muy posiblemente

${ }^{20}$ Es, en todo caso, un apellido común, que llevan desde el célebre arquitecto cordobés autor del Museo pictórico y escala óptica (1715-1724) hasta algunos músicos de finales del siglo XVIII y comienzos del XIX, lo que puede producir cierta confusión.

${ }^{21}$ Estos y otros datos biográficos proceden del manuscrito conservado en la Biblioteca Nacional de Madrid titulado Genealogía, origen y noticias de los comediantes de España, que editaron N. D. Shergold y John E. Varey, 


\section{LUIS ANTONIO GONZÁLEZ MARÍN}

este Perneras es Antonio Palomino "el menor" (que, con buen criterio, evitaría firmar con el otro apelativo usado "por mal nombre", o quizá todavía no lo habría adquirido). El tal Perneras figuró como sobresaliente en la compañía de Juana de Orozco en los años 30, actuó en 1738 con la de Inestrosa y poco después formó compañía propia. Estaba casado con Francisca Vallejo, que por su marido adquirió el apodo de La Palomina, y compartieron cartel en varias producciones. Perneras y La Palomina fueron padres de María Teresa Palomino, la famosa Pichona que, ya de avanzada edad, tuvo un flirt distante con un maduro Giacomo Casanova cuando éste residió en Madrid, a pocos metros de la casa de $\mathrm{Nebra}^{22}$. Se sabe que La Palomina formó parte de la compañía de Manuel de San Miguel, la que había estrenado Las tres comedias en una en 1729, y cabe la posibilidad de que su marido, Antonio Palomino Perneras, posible copiante de la fuente musical superviviente cuatro años después del estreno, también participara en el mismo, y que realizara tiempo después la copia bien por deseo de conservación o tal vez con vistas a una posible reposición de la que no tenemos noticia concreta. Los Palomino estuvieron en activo no sólo en Madrid, sino en varias capitales españolas, entre las que se encontraba Valencia, lo que tal vez pueda concordar con el dato "se hizo en Valencia" que se lee en el libreto manuscrito. Pero también es posible que el Antonio Palomino que "trasladó" la música de Venus y Adonis fuese otro del mismo nombre, el que años después sería marido de Catalina Pacheco, la célebre Catuja, que también formó parte de la compañía de Manuel de San Miguel. A este Palomino, hombre de teatro como los antes citados, se le tiene por compositor de alguna obra de Ramón de la Cruz, y se sabe que murió en 1801 contando ochenta años (Cotarelo y Mori, 1899: 562), por lo cual, de ser el copista de Venus y Adonis, habría realizado este trabajo cuando tenía doce años. Si la grafía del manuscrito musical no semeja, en principio, obra especialmente infantil, la copia parece manifestar una marcada inexperiencia, como se verá, y el apelativo de "el menor" podría casar bien con un mozalbete.

En cualquier caso, es sabido que las compañías teatrales de la época, que se formaban por temporadas, tenían mucho de empresa familiar, y que comúnmente encontramos lazos sanguíneos no sólo entre miembros de una misma compañía, sino entre componentes de varias, al tiempo que existía una notable flexibilidad -rivalidades aparte-, en el sentido de que los comediantes no figuraban en las compañías con exclusividad de por vida, sino que a menudo actuaban en cierto modo como artistas freelance, que, según temporadas, podían ser enrolados en una u otra compañía.

Si las conexiones entre la compañía que estrenó Venus y Adonis (Manuel de San Miguel) y las dos posibles identificaciones del copista que he propuesto parecen más que probables, también las hay entre dicha compañía y Manuel Guerrero, propietario del libreto conocido, que formó parte de la troupe de San Miguel durante algunos años. Aparte, como se ha visto, Guerrero estaba emparentado con los Palomino: de hecho, era sobrino carnal del mentado Perneras.

Fuentes para la Historia del Teatro en España, II (1985). El manuscrito puede consultarse en la Biblioteca Digital Hispánica. Existen numerosos documentos y publicaciones que refieren vidas y andanzas de comediantes del siglo XVIII, entre ellos los numerosos escritos de Emilio Cotarelo y Mori. Debe citarse además el interesante trabajo Les comédiennes-chanteuses à Madrid au XVIIIe siècle (1700-1767) (Bec, 2016).

${ }^{22}$ Véase mi artículo “Giacomo Casanova y la escena musical madrileña” (González Marín, 2015: 123-132). 


\section{ACERCa de LA RECUPERACIÓN DE VENUS Y ADONIS, DE JosÉ DE NEBRA}

Hay además un elemento que pone en relación Venus y Adonis con Valencia, además de la frase que se lee en el comienzo del libreto. La Biblioteca Nacional conserva una partitura manuscrita titulada LA DORINDA / MELODRAMA PASTORAL / Que se hà representado en el Palacio Real / de Valencia el dia 19 de Noviembre / Por el nombre de la / REYNA NRA. SRA. / Celebrando esta Fiesta / El Principe de Campo Florido. (E-Mn, M/2292). El año de la producción no figura en la fuente, ni tampoco el autor de la música, que viene siendo identificado con Francesco Corradini ${ }^{23}$. Si se trae a colación esta ópera pasticcio en tres actos con texto castellano es porque incorpora una importante concordancia con la ópera de Nebra: la música del aria final ("Tu amor y fineza que mi pecho adora”), en el acto tercero, antes de un largo recitativo y un coro de conclusión del espectáculo, coincide totalmente con la primera aria ("Mi airada venganza fulmine su enojo") de Venus y Adonis. El veneciano, criado en Nápoles, Francesco Corradini trabajó en Valencia, al servicio del capitán general y virrey, príncipe de Campoflorido, entre 1728 y 1731, antes de instalarse definitivamente en Madrid, donde compuso para diversas compañías teatrales, entre las cuales estaba la de Manuel de San Miguel, con la que se registran colaboraciones recurrentes desde el mismo 1731. Aun después de su traslado a Madrid, Corradini pudo continuar enviando música al príncipe de Campoflorido, que siguió patrocinando espectáculos en Valencia hasta su marcha como embajador a Venecia en 1737. Si tradicionalmente, y sin pruebas de ello, se ha fechado La Dorinda en 1728 (Llorens Cisteró, 1999 ss) y se ha tenido por obra de Corradini, investigaciones más recientes retrasan su puesta en escena hasta tal vez 1736, o en todo caso a la década de los 30 y confirman que se trató de un típico pasticcio que recogía arias de obras precedentes, tomando como base una pieza con música de Gasparini estrenada en Roma en 1725 e incorporando, por ejemplo, un aria del Artaserse de Metastasio y Leonardo Vinci, que se estrenó en Roma en 1730 (Bombi, 2004: 87-107). Aunque con los datos a disposición sea imposible asegurar si la composición del aria que abre Venus y Adonis corresponde a Nebra, a Corradini o a un tercero, sí puede argumentarse que, si la copia de Venus y Adonis de 1733 se corresponde con la música del estreno, el aria sería anterior a la producción valenciana de La Dorinda, por lo que tendría sentido adscribirla a la mano de Nebra. Por otro lado, estilísticamente casa a la perfección con el resto de la música dramática de Nebra que conocemos, conservada en fuentes autógrafas o más o menos autorizadas y, en todo caso, el texto que el aria tiene aplicado en $V$ enus y Adonis encaja con la música vigorosa y hasta cierto punto fiera, mucho mejor que con la letra amorosa que se le asigna en La Dorinda. Sea como fuere, tiene sentido pensar que una copia de Venus y Adonis pudo llegar fácilmente a manos de Corradini, que colaboró con dos de los implicados en el estreno y la conservación de Venus y Adonis (Manuel de San Miguel y Manuel Guerrero) en el entorno del teatro de los Caños del Peral, donde también actuó por esos años Antonio Palomino (Cotarelo y Mori, 1917: 93); y a la inversa, que Nebra tenía la posiblidad de manejar asiduamente composiciones del veneciano. Ambos músicos coinciden durante años en el ámbito de los teatros públicos madrileños, y hay que decir que Corradini se postuló para ocupar un par de

\footnotetext{
${ }^{23}$ Como tal, como ópera de Corradini, ha sido interpretada y grabada en CD una selección por Marian Rosa Montagut y su grupo Harmonia del Parmàs (2017). La Dorinda / Francesco Corradini (1690c.-1769). Valencia: Tempus TMP 003.
} 


\section{LUIS ANTONIO GONZÁLEZ MARÍN}

puestos en la corte que recayeron en el aragonés (el cargo de organista primero de la Real Capilla, vacante en 1736 por muerte de Diego de Lana, y el de vicemaestro en 1739, puesto inexistente que se creó años más tarde, en 1751, para Nebra) ${ }^{24}$. Las relaciones entre ambos compositores, aún por explorar en profundidad, pueden aportar novedades.

En cuanto a la conservación de la fuente musical, al presente se desconoce cómo llegó este manuscrito a manos de Nemesio Otaño. El polifacético organista y musicólogo jesuita es hoy conocido por sus composiciones, sus investigaciones en el campo del folklore, sus trabajos editoriales, la fundación de la Schola cantorum de Comillas, etc., pero muy especialmente por sus labores de gestión y control, fuertemente ideologizado, en diversos ámbitos en la primera etapa del franquismo (la dirección del Conservatorio de Madrid, su participación en el Comisariado de la Música, su intervención más o menos indirecta en la creación del Instituto Español de Musicología del CSIC, la vigilancia de programaciones y críticas...), y por sus trabajos sobre música militar española histórica, de resultas de los cuales nació, por ejemplo, la sintonía de los noticiarios de Radio Nacional, que, arreglada por él -y generando pingües beneficios en derechos-, sonó durante varias décadas ${ }^{25}$. Según parece, Otaño, que por su posición preeminente en los asuntos culturales del régimen pudo disfrutar de privilegiado acceso a fondos públicos y privados, coleccionó cierto número de documentos y fuentes musicales del siglo XVIII, tal vez vinculados de algún modo a sus investigaciones sobre los toques militares. Entre estas fuentes se encuentran obras (música escénica y de cámara, especialmente) manuscritas e impresas de autores como Corelli, Steffani, Alessandro Scarlatti, Handel, Pergolesi, Porpora, Gluck, Johann Christian Bach, Boccherini, Haydn, Abel, Pleyel, Salieri... y la ópera de Nebra en cuestión. De algunos de los volúmenes y cuadernillos (entre los que no se encuentran los cuadernos que contienen Venus y Adonis) puede rastrearse su procedencia, pues conservan en sus encuadernaciones un ex libris impreso de Manuel Delitala, a quien podemos identificar con el Marqués de Manca (*Barcelona, 1742; †Burgos, 1832), noble de origen sardo, diplomático en las cortes de Carlos III y Carlos IV, músico aficionado y buen amigo de Tomás de Iriarte, con el cual, entre otros, tocaba cuartetos de Haydn en las academias o veladas musicales que Delitala organizaba en su casa de la madrileña Carrera de San Francisco ${ }^{26}$.

La fuente musical de Venus y Adonis, por desgracia, no trae más indicaciones de procedencia que las de su copiante en 1733, Antonio Palomino. En cualquier caso, como ya se ha dicho, la copia debió de confeccionarse con vistas a algunas representaciones de la

\footnotetext{
${ }^{24}$ Algunos datos en Leza Cruz (1996-1997: 123-146).

25 Sobre la polifacética y controvertida figura de Otaño pueden verse José López-Calo (2010), y la tesis doctoral de Albano García Sánchez (2014).

${ }^{26}$ Véase Cotarelo y Mori, 1897. La imagen de Delitala e Iriarte tocando juntos cuartetos de Haydn junto con la anécdota del primero resoplando al enfrentarse a pasajes complicados -que le valió el apodo de "Ronquido" por parte del ingenioso Iriarte-, recogida por Cotarelo, ha sido repetida en otros trabajos posteriores, pero se ha realizado hasta ahora una investigación seria sobre la música en la casa de Manuel Delitala y Timboni. La presencia de estos fondos recogidos por Otaño, sobre los que se prepara una próxima publicación, contribuirá al conocimiento de las prácticas musicales en casas de la nobleza en la segunda mitad del siglo XVIII.
} 


\section{ACERCa de La ReCuperación de VENUS y ADONIS, DE José de Nebra}

obra. Lo que pongo en duda, sin embargo, es que llegara a utilizarse, por las razones que a continuación se verán.

Como apuntaba más arriba, tengo la impresión de que tanto el hecho de que el manuscrito musical de Venus y Adonis se encuentre incompleto como la insistencia en esta circunstancia por parte de Martín Moreno y, después, Álvarez Martínez, han disuadido a posibles interesados -musicólogos e intérpretes- de intentar recuperar la obra. Es cierto que el manuscrito está incompleto, pero únicamente en sentido "vertical", y no "horizontal". La sustancia del drama musical, esto es, las partes vocales al completo y el acompañamiento, se conserva y, además, el texto que ofrecen la fuente musical y el libreto manuscrito es idéntico, con la salvedad de mínimas variantes de escaso valor. A esto hay que añadir la existencia de la parte de violín primero, ordinariamente la más relevante y significativa de las partes orquestales. Vista la calidad general de la música de Nebra y la que parecía ofrecer esta obra, me decidí a preparar una edición y completar lo que falta, para interpretarla. Contando con el esqueleto que aportan las partes supervivientes y la ayuda de otras fuentes de Nebra, muchas de ellas autógrafas, me decidí a abordar una reconstrucción, que de entrada se preveía más o menos costosa según las características de los diversos números de la ópera. Ahora bien, la propia fuente musical se reveló como mucho más problemática de lo que cabía esperar.

El primer paso, lógicamente, consistía en preparar una transcripción limpia de todo el material musical aportado por las fuentes, esto es, disponer de una partitura correcta que incluyese la parte del violín 1, voces y continuo. Este trabajo, aparentemente simple, se ha visto dificultado por un problema de partida, que ha atravesado todo el proceso: el manuscrito de Palomino está lleno de errores y negligencias de copia, que la razonable caligrafía del amanuense no invitaba a presagiar. Estas erratas de copia son muy frecuentes y se dan en diversos niveles: alteraciones que faltan o que se colocan incorrectamente, notas que se sitúan de modo impreciso entre línea y espacio, notas que se han ubicado un espacio o una línea por encima o por debajo del lugar que les correspondería, figuras y silencios erróneos (por ejemplo, semimínima por mínima, o corcheas por semicorcheas), confusiones en puntillos, etc. Los errores en figuras y silencios se traducen a menudo en problemas de concordancia entre las partes del violín y de voz y bajo. En algunas ocasiones parece obvio que Palomino dejó de copiar medio compás o un compás entero, quedando algunas frases y progresiones truncadas... Son, en fin, errores típicos de un original "malo", a los que se encuentra solución, a veces al golpe de vista, a veces tras ciertos quebraderos de cabeza.

Hay muchas posibles explicaciones para la baja calidad musical del manuscrito. Para empezar, no es seguro que se deban achacar a Palomino los errores. No sabemos de dónde copió, qué manuscrito usó como modelo. Si copió de un autógrafo de Nebra similar a los que conocemos (pulcros, ordenados, meticulosamente anotados...), Palomino no tendría perdón. Pero tal vez tuvo en su mano un borrador o una copia de más difícil lectura para él 


\section{LUIS ANTONIO GONZÁLEZ MARÍN}

(posiblemente materiales de su ejecución, en posesión de una compañía teatral) o quizá un manuscrito que ya contenía errores. Cabe también la posibilidad de que Palomino careciera de experiencia musical, que fuera un zagal de doce años con buena caligrafía (si en efecto se trata del segundo candidato a copista que he propuesto anteriormente); o simplemente que copiara con prisas y sin mucho pensar. En todo caso, lo que el manuscrito demuestra es que difícilmente pudo ser utilizado en la práctica tal como está, sin enmiendas. Por eso anticipaba que tengo la impresión de que esta copia de Palomino no llegó a usarse para representar el melodrama.

Volviendo a la reconstrucción, los recitativos, en principio, no han planteado esta clase de problemas: no había nada que reconstruir, pues las dos partes de la composición voces y línea del acompañamiento- se encuentran, en partitura, en uno de los cuadernos que se conservan, el destinado posiblemente al clave. Sin embrago, los citados errores y negligencias de copia han exigido largas reflexiones y profundas revisiones. Aunque la parte de violín 1 parece desmentir la existencia de algún recitativo accompagnato, pues no se indica tal cosa, me he tomado la libertad de reconstruir uno, o más bien de transformar un recitado convencional, sustentado sólo por el continuo en la fuente, en un accompagnato con intervención de toda la cuerda. Sabemos que en la tradición operística desde comienzos del XVIII el accompagnato se suele reservar para escenas y momentos cargados de especial afecto. Nebra no era ajeno a la tipología de composición ni a la convención, como demuestra en Amor aumenta el valor, donde introduce un accompagnato en un momento de clímax emocional y musical (el recitado "Triste cárcel oscura", que precede a la conocida aria "Ay, amor"). Precisamente, el parentesco musical, en cuanto a procedimientos compositivos, del último recitado a solo de Venus en Venus y Adonis ("No triunfa el hado") con "Triste cárcel oscura", su estatismo y su carácter modulante, así como la cualidad fuertemente emotiva del momento que representa (el instante en que la doliente Venus se dispone a revivir, en forma floral, a su amado Adonis), me invitaron a escribir partes de violín 1, violín 2 y viola, y a interpretar "No triunfa el hado" en estilo accompagnato. Es la mayor de las licencias que me he permitido en la reconstrucción de Venus y Adonis, pues la fuente no la justifica, aunque seguramente ni la música ni el drama la desaconsejen.

En el caso de las arias y dúos, los cuadernos conservados de la fuente musical nos ofrecen, como se ha dicho, casi todo lo sustancial, esto es, las voces y el bajo por un lado y la línea instrumental principal de la orquesta -el violín primero- por otro. La partitura vocal y a veces la parte del violín presentan además algunas anotaciones de instrumentación que, a falta de las partes correspondientes, han sido de gran utilidad. Gracias a estas anotaciones sabemos que en algunos números intervinieron instrumentos de metal (una pareja de trompas y un clarín), utilizados con notable sentido simbólico, en diferentes niveles.

En ningún lugar de la fuente se mencionan oboes, ni tampoco flautas. Sabemos que las segundas, fueran dulces o traveseras, solían utilizarse convencionalmente para 


\section{ACERCA DE LA RECUPERACIÓN DE VENUS Y ADONIS, DE JOSÉ DE NEBRA}

caracterizar determinadas situaciones (sueño, muerte, ultratumba... $)^{27}$; en cambio, los primeros, usados en pareja, formaban parte ordinariamente del grueso de la orquesta, junto a la cuerda y en unísono con las partes de violín (a veces sólo con el primero, a veces emparejados: violín $1+$ oboe 1 , violín $2+$ oboe 2 ) excepto en las ocasiones en que disponían de partes propias, obligadas ${ }^{28}$. Francisco Valls, en su Mapa armónico, da cuenta, indirectamente, de estas habituales duplicaciones cuando afirma que "el estilo de Música entre violines, oboesses, y flautas casi es el mismo, pues lo que executa el violín, lo practica el oboé, y la flauta..." (Valls, 1742: f. 144r) ${ }^{29}$. Pero, además, en algunos manuscritos autógrafos de música teatral, el propio Nebra da a entender que los oboes suenan regularmente en unísono con la cuerda en arias, dúos, coros, etc., cuando indica que determinado número se toca "sin obues" o proscribe su uso en un recitativo accompagnato, en el que obviamente sólo interviene la cuerda junto al continuo: es lo que encontramos, por ejemplo, en la fuente musical autógrafa de Vendado Amor es, no ciego (1744), donde el Minué I de la Obertura viene titulado "Minue sin obues", indicación ("sin obues") que reaparece en el encabezado de un aria de Venus ("Quién, cielos, de Adonis") o en el accompagnato "Estos tejidos lazos" ("Recitado Eumene sin obues And[an]te") ${ }^{30}$. Aunque las referidas indicaciones de Nebra a los oboes en unísono con la cuerda sean posteriores a Venus y Adonis, ninguna razón nos invita a pensar que la costumbre, radicada en Francia desde época de Lully y en el resto de Europa desde al menos comienzos del siglo XVIII, no fuera conocida y practicada por el compositor en sus obras de la década de los 20 . Y, en todo caso, desde el punto de vista musical resulta convincente y aconsejable.

En cuanto a la cuerda, aunque en la práctica musical española con frecuencia se reducía a dos partes de violín, sin viola (tal vez en línea con la sintomática apreciación de Valls hacia el uso de este instrumento: "Los Italianos, en algunas obras, acostumbran a los dos violines, añadirles una violetta que es un contralto; pero en bulla de instrumentos, casi no se oye" [Valls, 1742: f. 145r]), parece que Nebra, si disponía de la oportunidad, la usó regularmente en sus composiciones orquestales (más allá de sus piezas de corte más camerístico, como cantadas, u obras destinadas a la exportación -villancicos en su mayoría-,

\footnotetext{
27 Sobre los usos simbólicos comvencionales de las flautas en el barroco, véanse mis introducciones a las ediciones siguientes: José de Nebra: Oficio y Misa para las Reales Honras de la Reina Da. María Bárbara, que goza de Dios (González Marín, 2003) y Giacomo Facco / José de Nebra: Amor aumenta el valor (González Marín, 2011).

${ }^{28}$ En Amor aumenta el valor Nebra utilizó, en ocasiones, partes obligadas de oboes, diferentes de las de los violines, pero estoy convencido de que intervenían en el resto, en unisono con la cuerda, aunque no se indique en la partitura. Véase de nuevo mi edición citada. Puede escucharse una grabación completa, siguiendo estos criterios, en Los Músicos de Su Alteza (dir. Luis Antonio GONZÁLEZ) (2010). José de Nebra: Amor aumenta el valor. París: Alpha (Colección Ut pictura musica) [Entidades patrocinadoras: Université Laval (Québec, Canadá), Fondation Orange, Gobierno de Aragón], ALPHA 171.

${ }^{29}$ Valls, F. (1742). Mapa harmónico práctico [manuscrito], en su edición facsímil al cuidado de Joseph Pavia i Simó publicada en 2002 en Barcelona por el CSIC. Algunos comentarios sobre el uso duplicado de instrumentos de viento, ya en época más temprana, se encuentra en mi artículo "Algunas consideraciones sobre la música para conjuntos instrumentales en el siglo XVII español” (González Marín, 1997: 101-142).

${ }^{30}$ La fuente musical de esta zarzuela se encuentra en el Archivo de Múisca de las Catedrales de Zaragoza, y fue descubierta a finales de los años 80 del siglo XX, en los inicios de la catalogación sistemática del archivo que realizó el equipo formado por José V. González Valle, Antonio Ezquerro Esteban y quien firma este artículo. Existe una edición de María Salud Álvarez Martínez (1999) que, lamentablemente, oculta tales indicaciones en la partitura y, en consecuencia, deja de incluir los oboes en los números en los que, no obstante, su uso está perfectamente sobreentendido.
} 


\section{LUIS ANTONIO GONZÁLEZ MARÍN}

aptas para ser utilizadas en lugares donde no tenía por qué haber violas, pero sí violines). Nebra utiliza la cuerda a cuatro (dos violines, viola y bajo) tanto en composiciones teatrales tempranas de corte (Amor aumenta el valor) como más tardías para teatros públicos (las cuatro zarzuelas supervivientes: Viento es la dicha de Amor, Vendado Amor es, no ciego, Donde hay violencia no hay culpa, y Para obsequio a la deidad nunca es culto la crueldad, y Iphigenia en Tracia), aunque las fuentes de otras tipologías (autos sacramentales, bailes, sainetes, incluso de los años 50) no conserven partes de viola; y por supuesto lo hace en su música litúrgica, destinada o no a la Real Capilla (es el caso, por ejemplo, del Miserere a dúo, cuyas previsiones de uso no nos son conocidas ${ }^{31}$ ).

Acerca de la composición de la orquesta y sus dimensiones en los teatros públicos, disponemos de un documento muy valioso relativo a las representaciones de la zarzuela $L a$ colonia de Diana, de Nicolás González Martínez con música de José de Nebra, en 1745 en el teatro del Príncipe. En el manuscrito que se conserva en la Biblioteca Nacional de Madrid $^{32}$, bajo el reparto leemos un recuento de los instrumentistas:

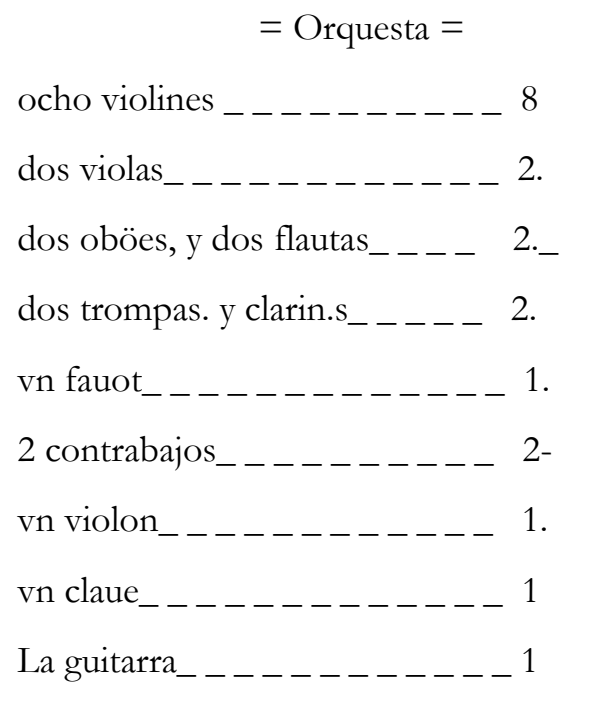

La distribución, que pone de manifiesto que oboes y flautas eran soplados por los mismos instrumentistas, e idénticamente sucedía con trompas y clarines, se antoja totalmente equilibrada, salvo quizá en lo que respecta a los dos contrabajos frente a un violón. Puede que se trate de una errata y se quisiera decir lo contrario, pero me inclino a pensar que la idea de cómo ha de constituirse una agrupación orquestal en la actualidad no

\footnotetext{
31 Una reflexión sobre esta obra, que tal vez no fuera compuesta para la Real Capilla (como sugiere el hecho de que las tres fuentes supervivientes se conserven en lugares alejados de la Corte -Zaragoza y Guatemala- y ninguna en el Archivo de Palacio) se encuentra en mi estudio y edición José de Nebra: Miserere a dúo. Miserere a ocho (González Marín, 2010).

$32 \boldsymbol{E}-\mathrm{Mn}$, Res/60, f. 2 r.
} 


\section{ACERCa de LA RECUPERACIÓN DE VENUS Y ADONIS, DE JosÉ DE NEBRA}

es necesariamente la misma del siglo XVIII. En ciertos espacios de acústica seca -y los coliseos o teatros a la italiana, como era ya el del Príncipe en esas fechas, tienden a serloque privilegia las voces y las frecuencias altas, reforzar los contrabajos puede ser muy ventajoso, y aun necesario. De hecho, este tipo de combinación se repite en diferentes nóminas de orquestas de teatros madrileños a lo largo de la segunda mitad del siglo XVIII ${ }^{33}$.

El documento citado resulta algo tardío en comparación con Venus y Adonis, pero el equilibrio sonoro que propone parece sumamente acertado como "ideal" para obras que han de interpretarse en un teatro y piden además el uso de instrumentos de metal (las trompas y el clarín en Venus y Adonis). Una orquesta de esas dimensiones ofrece un balance perfecto, y por esta razón me decidí a plantear la reconstrucción instrumental de Venus y Adonis con estas premisas, en lo que se refiere a la recomposición de partes y también a la interpretación.

Disponiendo, por tanto, de un buen esqueleto orquestal (violín 1 y acompañamiento), además de las partes vocales, y de algunas fuentes documentales y musicales que servían de ayuda, ha sido preciso emprender una reconstrucción verosímil, discreta pero efectiva. Para la reconstrucción de las partes instrumentales que faltaban me he basado: 1) en las didascalias (por ejemplo: "aria con trompas de caza"...); 2) en las listas de orquestas de teatros públicos madrileños en la época; y sobre todo 3) fundamentalmente, en otras obras de Nebra conservadas en fuentes autógrafas o autorizadas, de cuyo estudio minucioso he extraído procedimientos y maneras, de modo que el resultado fuera creíble y convincente. Naturalmente, la orquestación del aria conservada en La Dorinda se ha mantenido, pues, de no ser de Nebra, al menos es estrictamente contemporánea y válida. He procurado no excederme en libertades compositivas; al contrario, en todo momento me he ceñido a procedimientos de composición instrumental que he podido examinar en otras obras, particularmente teatrales, de José de Nebra. De gran utilidad ha sido el trabajo con las zarzuelas y autos sacramentales que Nebra compuso en décadas posteriores, pero sobre todo ha resultado decisivo el conocimiento de Amor aumenta el valor, obra también temprana en la producción teatral de Nebra conservada, con la que Venus y Adonis comparte muchos elementos comunes. Uno de ellos, que tiene que ver con la notación y con la práctica, es que tanto en Amor aumenta el valor como en Venus y Adonis Nebra escribe numerosísimas apoyaturas en los recitativos, cosa que hace con mucha mayor parquedad en los recitativos de las obras dramáticas más modernas (de los 40 en adelante) que se han conservado, como sucede en los autógrafos de Vendado Amor es, no ciego o Donde hay violencia no hay culpa. Seguramente este cambio de notación no responde tanto a una variación de estilo a la hora de cantar los recitativos como al desarrollo de una práctica: posiblemente la superabundancia de signos de apoyatura en las obras más tempranas respondía a una necesidad, pues tal vez en los años 20 las cantantes no estaban tan habituadas a las convenciones del estilo recitativo a la italiana y el autor consideraba conveniente precisar las apoyaturas, que años más tarde ya

33 Véase Barba, 2015: 165-185. 


\section{LUIS ANTONIO GONZÁLEZ MARÍN}

formaban parte de la costumbre a la hora de cantar recitativos, haciendo innecesario anotar tales figuras.

El parentesco con Amor aumenta el valor puede rastrearse en diferentes niveles, hasta el punto de que podemos encontrar similitudes temáticas -musicales- muy evidentes en algunas arias de una y otra producción. El caso más obvio se encuentra, sin duda, en la última de las arias de Venus, cuyo material motívico trae a la memoria, indefectiblemente, el aria de Porcia en Amor aumenta el valor ${ }^{34}$.

Nebra hace un uso simbólico de algunos instrumentos, o de ciertos procedimientos de ejecución, como ya se podía ver en Amor aumenta el valor. Si en esta ópera las flautas evocaban un momento de ensoñación y proximidad de la muerte y las cuerdas en punteado (pizzicato) representaban los latidos del corazón ${ }^{35}$, en Venus y Adonis la escena del sueño amoroso se acompaña con cuerdas con sordina ${ }^{36}$, mientras se reitera el uso del punteado para marcar los latidos del protagonista, Adonis, poco antes de morir, en una preciosa "aria sin da capo" "37; la propia ausencia de esta convención compositiva, el da capo, viene más que justificada por la acción dramática: el personaje que muere en escena, en el momento de clímax de la representación, no tiene tiempo de andarse con repeticiones. El clarín es requerido en un aria de carácter bélico ${ }^{38}$, mientras las trompas aluden convencionalmente a la caza y la lucha ${ }^{39}$, pero también, de manera irónica, a la cornamenta recién adquirida por Marte, sabedor de que su amante Venus se ha enamorado de Adonis ${ }^{40}$.

No hay lugar aquí para un análisis más profundo, en lo que a dramaturgia musical se refiere, de Venus y Adonis. Confío en poder ofrecerlo en una próxima edición crítica de la pieza. Tampoco hay espacio para extenderse sobre el uso de elementos populares o tradicionales en los papeles de los graciosos. Baste decir que Venus y Adonis contiene, en el aria de Celfa, el más antiguo fandango orquestal que conocemos hasta ahora, como he expuesto en otro lugar ${ }^{41}$. La música que Nebra compuso para Venus y Adonis, de una calidad incuestionable, podrá dar pie a trabajos sucesivos, planteados desde diferentes perspectivas.

\footnotetext{
34 Me refiero al aria de Venus "En flor tu vida crezca", número 38 de Venus y Adonis, y al aria de Porcia "Como el céfiro corre" en Amor aumenta el valor.

${ }^{35}$ Esto sucede en la célebre aria de Horacio "Ay, amor, ay, Clelia mía”.

36 Aria "Ay, Venus bella", número 16.

37 "Adiós, Venus bella", número 36.

${ }^{38} \mathrm{El}$ aria de Adonis "Silbo del aire veloz", número 27.

39 El aria de Venus "Trompas venatorias", número 18, donde tal vez se haga un juego de palabras con el término "venatorias", relativo a la caza pero con la misma raíz que Venus.

${ }^{40} \mathrm{El}$ aria de Marte "Tan vano es pretender", número 33.

${ }^{41}$ El aria de Celfa "Cualquiera mozuela", número 22. Sobre este y otros fandangos, véase mi artículo "Early Examples of Spanish Dances in the Music of José de Nebra”, en Goldberg, Pizà Prohens y Clark (2019).
} 


\section{ACERCA DE LA RECUPERACIÓN DE VENUS Y ADONIS, DE JOSÉ DE NEBRA}

Entretanto, la ópera se ha estrenado ${ }^{42} \mathrm{y}$, a falta de grabación discográfica, uno de los conciertos fue filmado por Televisión Española ${ }^{43}$ y grabado por Radio Nacional de España. Asimismo, se está realizando un film documental ${ }^{44}$ sobre el proceso de recuperación de Venus y Adonis, una experiencia muy trabajosa pero sumamente satisfactoria.

\section{BIBLIOGRAFÍA}

Álvarez Martínez, M. S. (1999). Vendado es Amor, no es ciego. Zaragoza: Institución Fernando el Católico.

Álvarez Martínez, Ma. S. (1993). José de Nebra Blasco. Vida y obra. Zaragoza: Institución Fernando el Católico.

Andioc, R. y Coulon, M. (1996). Cartelera teatral madrileña del siglo XVIII: (1708-1808). Toulouse: Presses Universitaires du Mirail.

Barba, M. (2015). "Las orquestas de los coliseos madrileños Príncipe y Cruz durante la segunda mitad del siglo XVIII”. Cuadernos dieciochistas, 16, pp. 165-185.

Barrera y Leirado, C. A. de la (1860). Catálogo bibliográfico y biográfico del teatro antiguo español: desde sus orígenes hasta mediados del Siglo XVIII. Madrid: Imprenta y Estereotipia de M. Rivedeneyra.

Bec, C. (2016). Les comédiennes-chanteuses à Madrid au XVIIIe siècle (1700-1767). París: Honoré Champion.

\footnotetext{
42 El estreno "mundial" de esta recuperación tuvo lugar en la Sala Mozart del Auditorio de Zaragoza, por Los Músicos de Su Alteza, bajo mi dirección, el 8 de noviembre de 2018, con arreglo al siguiente reparto: Venus, Olalla Alemán; Adonis, Eugenia Boix; Marte, María Hinojosa; Cibeles, Marta Infante; Celfa, Aurora Peña; Clarín, José Pizarro. Orquesta barroca Los Músicos de Su Alteza (Grupo Residente del Auditorio de Zaragoza): flauta, Pepa Megina; oboes, Francisco J. Gil y Pepa Megina; fagot, Joaquim Guerra; clarín, Gerard Serrano; trompas, Gerard Serrano y Pepe Reche; violines, Eduardo Fenoll, Pablo Prieto, Liz Moore, Sergio Franco, Juan Bernués, Raquel Sobrino, Marta Fernández Escamilla, José Manuel Fuentes; violas, Juan Luis Arcos y Daniel Lorenzo; violones, Pedro Reula y Ester Domingo; contrabajo, Roger Azcona; archilaúd y guitarra, Josep Maria Martí; clave, Alfonso Sebastián. Posteriormente se interpretó, con idéntico reparto, en la Sala Sinfónica del Auditorio Nacional de Madrid el 18 de noviembre de 2018, dentro de la programación "Universo Barroco" del Centro Nacional de Difusión Musical (CNDM) del INAEM, Ministerio de Cultura.

${ }^{43}$ La filmación de TVE puede verse en este enlace: http://www.rtve.es/alacarta/videos/los-conciertos-de-la2/conciertos-2-cndm-opera-nebra-venus-adonis/4925198/

44 Este documental, producido por Albella Audiovisual y dirigido por José Manuel Herraiz, ha recibido ayudas de la Diputación de Zaragoza y Aragón Televisión, y se presentará en 2019.
} 


\section{LUIS ANTONIO GONZÁLEZ MARÍN}

Bombi, A. (2004). "Una ópera italiana de exzelente música. Exordios del dramma per musica en Valencia”, en F. C. Bueno Camejo y J. A. Alberola Verdú (Eds.), III Jornadas Nacionales de música, estética y patrimonio. Actas de las jornadas, Xátiva, 4,5 y 6 de julio de 2003, pp. 87-107. Xàtiva: Ajuntament de Xàtiva, Regidoria de Música.

Borrego Gutiérrez, E. y González Marín, L. A. (Eds.) (2008). La divina Filotea. Auto sacramental de Pedro Calderón de la Barca (1600-1681). Música de José de Nebra (1702-1768). Madrid: Fundación CajaMadrid.

Cotarelo y Mori, E. (1897). Iriarte y su época. Madrid: Establecimiento Tipográfico "Sucesores de Rivadeneyra".

Cotarelo y Mori, E. (1899). Don Ramón de la Cruæy y sus obras: ensayo biográfico y bibliográfico. Madrid: Imprenta de José Perales y Martínez.

Cotarelo y Mori, E. (1917). Origenes y establecimiento de la ópera en España hasta 1800. Madrid: Tipografía de la "Revista de Archivos, Bibliotecas y Museos".

Di Pinto, E. (2015). "Entremés nuevo La burla del alcaide de la cárcel, de Guerrero: un híbrido del quehacer teatral de los siglos XVII y XVIII”, en J. M. Díez Borque, Á. Bustos Táuler y E. Di Pinto (Eds.), Miscelánea teatral áurea, pp. 97-140. Madrid: Visor.

García Sánchez, A. (2014). El músico José Maria Nemesio Otaño Eguino (1880-1956). Perfil biográfico, pensamiento estético y análisis de su labor propagandística y gestora. Tesis Doctoral. Oviedo: Universidad de Oviedo.

Goldberg, M; Pizà Prohens, A. y Clark, W. A. (Eds.) (2019). Spaniards, Natives, Africans and Roma: Transatlantic Malagueñas and Zapateados in Music, Song and Dance. Cambridge: Cambridge Scholars Publishing (en prensa).

González Marín, L. A. (1993). "El teatro musical español del siglo XVII y sus posibilidades de restauración”. Anuario Musical. Revista de musicología del CSIC, 48, pp. 63-102.

González Marín, L. A. (1997). “Algunas consideraciones sobre la música para conjuntos instrumentales en el siglo XVII español". Anuario Musical. Revista de musicología del CSIC, 52, pp. 101-142.

González Marín, L. A. (2002). Antonio Literes: Acis y Galatea [Música Hispana, 37]. Madrid: Instituto Complutense de Ciencias Musicales, Fundación Autor. 


\section{ACERCa de La ReCuperación de VENUS y ADONIS, DE José de Nebra}

González Marín, L. A. (2003). José de Nebra: Oficio y Misa para las Reales Honras de la Reina Da. Maria Bárbara, que goza de Dios. Madrid: Instituto Complutense de Ciencias Musicales, Fundación Autor.

González Marín, L. A. (2008a). “Apunte biográfico de José de Nebra”, "El legado zaragozano de José de Nebra", "José de Nebra y los autos sacramentales", "La fuente musical y la producción de La divina Filotea" y "La música de La divina Filotea", en E. Borrego Gutiérrez y L. A. González Marín (Eds.), La divina Filotea. Auto sacramental de Pedro Calderón de la Barca (1600-1681). Música de José de Nebra (1702-1768), pp. 11-29. Madrid: Fundación CajaMadrid.

González Marín, L. A. (2008b). "Una reflexión sobre la música de tecla de José de Nebra”, en Delantera de paraíso. Estudios en homenaje a Luis G. Iberni, pp. 591-612. Madrid: Instituto Complutense de Ciencias Musicales.

González Marín, L. A. (2010). José de Nebra: Miserere a dúo. Miserere a ocho. Madrid: Instituto Complutense de Ciencias Musicales, Arteria Promociones Culturales.

González Marín, L. A. (2011). Giacomo Facco / José de Nebra: Amor aumenta el valor. Madrid: Instituto Complutense de Ciencias Musicales, Arteria Promociones Culturales.

González Marín, L. A. (2015). “Giacomo Casanova y la escena musical madrileña”, en M. Nagore y V. Sánchez (eds.). Allegro cum laude: Estudios musicológicos en homenaje a Emilio Casares, pp. 123-132. Madrid: Instituto Complutense de Ciencias Musicales.

González Marín, L. A. (2016). “A vueltas con José de Nebra. Pensamientos sobre autorías y atribuciones”, en P. Capdepón Verdú y J. J. Pastor Comín (Eds.), El patrimonio musical de Castilla-La Mancha: nuevas perspectivas, pp. 91-108. Madrid: Alpuerto.

González Marín, L. A. (2019). "Early Examples of Spanish Dances in the Music of José de Nebra", en M. Goldberg;; A. Pizà Prohens y W. A. Clark (Eds.): Spaniards, Natives, Africans and Roma: Transatlantic Malagueñas and Zapateados in Music, Song and Dance. Cambridge: Cambridge Scholars Publishing (en prensa).

Kleinertz, R. (2003). Grundž̈ge des spanischen Musiktheaters im 18. Jabrbundert. Opera - Comedia - Zarzuela. Kassel: Reichenberger. 


\section{LUIS ANTONIO GONZÁLEZ MARÍN}

Leal Bonmatí, M. R. (2007). “José de Cañizares (1676-1750): Un panorama crítico, una reivindicación literaria”. Revista de Literatura, julio-diciembre, vol. LXIX, no 138, pp. 487-518.

Leza Cruz, J. M. (1996-1997). "Franceso Corradini y la introducción de la ópera en los teatros comerciales de Madrid (1731-1749)". Artigrama, 12, pp. 123-146.

Leza Cruz, J. M. (2011). José de Nebra / Antonio de Zamora: Viento es la dicha de Amor. Madrid: Instituto Complutense de Ciencias Musicales.

Llorens Cisteró, J. M. (1999ss.). “Corradini [Coradigni, Coradini], Francisco”, en Diccionario de la música española e hispanoamericana. Madrid: Instituto Complutense de Ciencias Musicales.

López-Calo, J. (1999ss.). "San Juan, José de", en Diccionario de la música española e hispanoamericana. Madrid: Instituto Complutense de Ciencias Musicales.

López-Calo, J. (2010). Nemesio Otaño, S. J. Medio siglo de música religiosa en España. Madrid: Instituto Complutense de Ciencias Musicales.

Martín Moreno, A. (1979). Sebastián Durón - José de Cañizares: Salir el Amor del mundo, zarzuela en dos jornadas. Madrid: Sociedad Española de Musicología.

Martín Moreno, A. (1985). Historia de la música española. IV. Siglo XVIII. Madrid: Alianza Editorial.

Pastor Comín, J. J. (2008). "Venus y Adonis: la transformación literaria del mito en la música europea del XVII”, en J. Herrero Cecilia y M. Morales Peco (Eds.), Reescrituras de los mitos en la literatura: estudios de mitocritica y de literatura comparada, pp. 131-150. Cuenca: Ediciones de la Universidad de Castilla-La Mancha.

[Paz y Meliá, A.] (1899). Catálogo de las piezas de teatro que se conservan en el Departamento de Manuscritos de la Biblioteca Nacional. Madrid: Imprenta del Colegio Nacional de Sordomudos y Ciegos.

Pérez Pastor, C. (1910). Noticias y documentos relativos a la historia y literatura españolas, Tomo X de las Memorias de la Real Academia Española. Madrid: Imprenta de la Revista de Legislación: 


\section{ACERCA de La RECUPERACIÓN DE VENUS Y ADONIS, DE JOSÉ DE NEBRA}

Pizà Prohens, A. (2002). Antoni Literes: Introducció a la seva obra. Palma de Mallorca: Edicions Documenta Balear.

Sáez, A. J. (2014). "Paradigmas y estructuras en las comedias triples del Siglo de Oro". Revista de Literatura, julio-diciembre, vol. LXXVI, no. 152, pp. 479-493.

Shergold, N. D. y Varey, J. E. (1985). Fuentes para la Historia del Teatro en España, II. Londres: Tamesis Books.

Stein, L. K. (1999). Tomás de Torrejón y Velasco y Juan Hidalgo: La púrpura de la rosa, fiesta cantada, ópera en un acto. Madrid: Instituto Complutense de Ciencias Musicales.

Valls, F. (1742). Mapa harmónico práctico [manuscrito]. Barcelona (edición facsímil al cuidado de Pavia i Simó, J. (2002). Barcelona: CSIC).

Yáñez Navarro, C. (2018). "La existencia en España de una tercera gran colección de sonatas de D. Scarlatti copiada por el escriba de los Manuscritos de Venecia (Libros I-XIII) y Parma (Libros I-XV)". Anuario Musical. Revista de Musicología del CSIC, 73, pp. 167-186.

Fecha de recepción: 19/11/2018

Fecha de aceptación: 29/11/2018 